MIRANDA GRANGE

300237003

\title{
CRIMINALISATION OF SEAFARERS - A NEW ZEALAND PERSPECTIVE
}

LAWS 582: LEGAL RESEARCH PAPER

FACULTY OF LAW

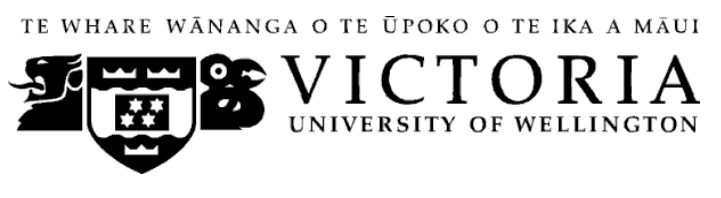

2015

Word length: The text of this paper (excluding table of contents, footnotes and bibliography, but including material footnotes) comprises approximately 11,943 words. 
I. INTRODUCTION

II. INTERNATIONAL CRIMINALISATION OF SEAFARERS ....................................................... 5

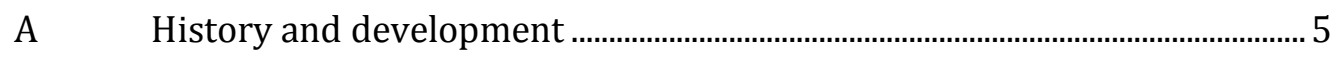

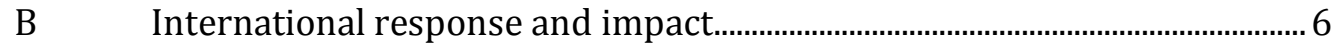

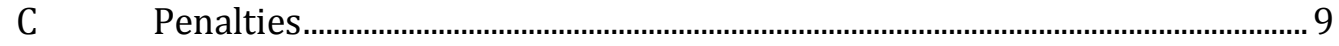

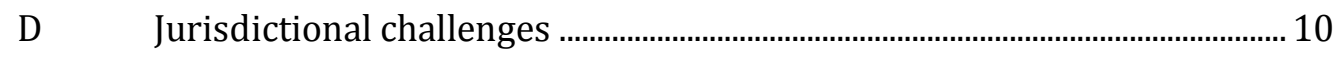

III. NEW ZEALAND MARITIME INDUSTRY …….................................................................. 11

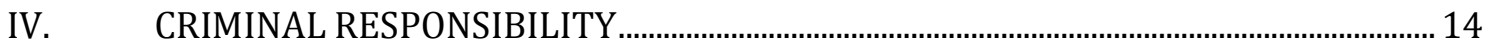

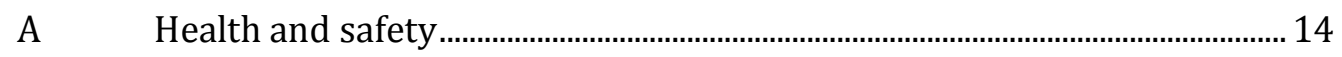

B Emergencies, collisions or accidents ................................................................. 24

C Employment rights and obligations ………........................................................ 27

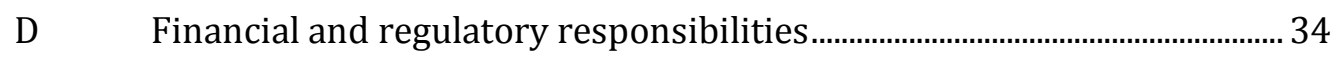

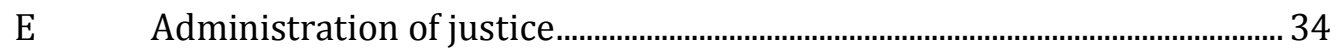

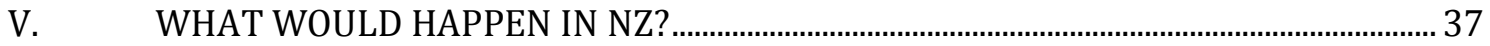

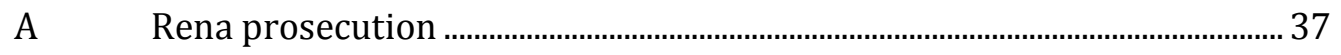

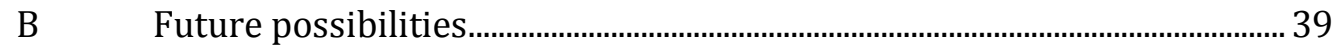

C What is the 'worst case scenario'? ..................................................................... 44

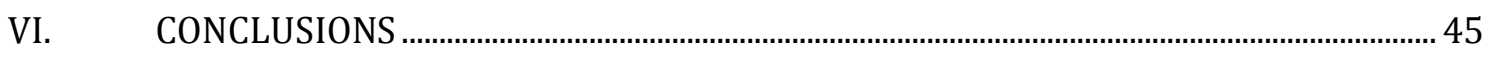

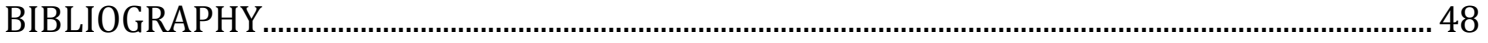




\section{Introduction}

Participants and observers of the maritime industry have been claiming a trend internationally towards criminalising the actions of seafarers in modern years. This trend has been apparent since the mid-20 th century and has many vocal industry participants declaring that it is disturbing and negatively impacts the maritime industry as a whole, particularly when the blame of large-scale pollution events are placed on seafarers themselves. The International Transport Workers' Federation ("ITWF") highlights these industry concerns: ${ }^{1}$

In the modern maritime industry, reduced crews are expected to affect fast turnarounds and take ever greater responsibility for maritime security and pollution prevention. On the one hand they are subject to pressure from the company to remain economically competitive at all costs. On the other hand they face the threat of heavy-handed sanctions by States eager to find scapegoats for politically sensitive cases involving environmental damage.

This paper looks at international discourse on this trend and examines whether it is reflected in New Zealand ("NZ") by focusing on the statutory reality of the increasing criminalisation thesis. This maritime industry is largely regulated by the Maritime Transport Act 1994 ("MTA"). However, as with all jurisdictions, maritime specific laws do not exist in a vacuum. The MTA operates alongside maritime rules; the Crimes Act 1961; the Resource Management Act 1991 ("RMA"); anti-terrorism measures; health and safety legislation; employee rights; human rights; and international obligations.

This research paper analyses the NZ dimension in the context of this international discussion. This paper has four main aims:

1) To isolate the areas where industry participants believe there is a trend towards greater criminalisation;

\footnotetext{
${ }^{1}$ International Transport Workers' Federation "Out of sight, out of mind: Seafarers, Fishers and Human Rights" June 2006 at 29. Challengers assert is that the "criminalisation of accidental pollution may discourage feedback regarding incidents, failures, and even accidents and so inhibit their prevention" as well as the increasingly employment costs that such criminal sanctions trigger: see Kyriaki Mitroussi "Employment of seafarers in the EU context: Challenges and opportunities" (2008) 32 Marine Policy at 1047.
} 
2) To analyse legislative and policy developments in NZ, focusing on the MTA and earlier legislation;

3) Determine whether NZ is following the international trend towards increased criminalisation of seafarers; and

4) Highlight infamous cases giving rise to liability in this area and hypothetically applies them to the NZ context.

The bulk of this paper focuses on the second aim above: Part IV identifies five areas of criminal responsibility. Every maritime offence and crime in NZ legislation has been examined. ${ }^{2}$ Part V is a forecasting exercise where I apply the facts of four international cases into the NZ framework and examine a 'worse case' scenario.

This paper focuses on offences applicable only to seafarers (including masters) of merchant ships, in the course of their professional duties. There are sundry offences in NZ law which apply to "every person" but this paper only examines these in the context of seafarers' professional duties. For example, offences under the recent legislation to combat piracy and terrorism through policing and border control - Maritime Crimes Act 1999 and Maritime Security Act 2004 - are outside the scope of this paper though both Acts are important pieces of legislation for NZ international obligations. ${ }^{3}$ I do not examine offences relating to harbour-masters; owners or employers of seafarers; warships or defence force members; port operators or facilities; pleasure craft; fishing boats; search and rescue operators; wrecks; nor marine structures and operations. ${ }^{4}$ Further, the paper does not look at the civil penalties for the same activities as examined in the criminal context, liability under the Maritime Insurance Act 1908, or the delegated authority of

\footnotetext{
2 For ease of discussion, Part IV divides these areas into (1) health and safety offences (including pollution and hazardous cargo situations); (2) emergency situations, collisions or accidents; (3) employment rights and obligations; (4) financial and regulatory responsibilities; and (5) obligations involving the administration of justice.

${ }^{3}$ See International Convention for the Safety of Life at Sea 1184 UNTS 1185 (opened for signature 1 November 1974, entered into force 25 May 1980).

${ }^{4}$ See sections 31(4) and 71(1) of the Maritime Transport Act 1994 [hereinafter referred to as the "MTA"]; Maritime New Zealand v Page [2013] DCR 102; and Sellers v Maritime Safety (5 November 1998) CA104/98.
} 
Maritime New Zealand ("MNZ"). 5 This scope has been chosen due to the parallel international discussion and concerns with this subject.

\section{International criminalisation of seafarers}

\section{A History and development}

While there is little legal scholarship on the background of maritime criminalisation, the claim of an international upward trend in criminalisation from industry proponents stems from the late 1980s. In March 1989, Captain Hazelwood four criminal charges relating to the grounding of his ship, Exxon Valdez: being intoxicated when operating a vessel; the negligent discharge of oil; criminal mischief; and reckless endangerment. ${ }^{6}$ Captain Hazelwood was eventually only convicted of a single charge after a staggering eight appeals - negligent discharge of oil - and received a sentence of 100 hours of community service in Alaska with a US $\$ 50,000$ fine. $^{7}$

Since this incident in 1989, industry groups claim that there are an alarming number of prosecutions which are characterised by a lack of negligent behaviour proven or admitted in court on the part of the master or other seafarers. This trend is particularly evident in pollution disasters. ${ }^{8}$ The facts of these cases vary and may happen in NZ as readily as they have in jurisdictions overseas. Criminal sanctions for

\footnotetext{
5 See Part 25 of the MTA.

6 John Hare "Criminalisation and Fair Treatment of Seafarers - Punishable Miscreants or Political Pawns?" (September 2011) The Nautical Institute Command Seminar, Cape Town at 3; and Ove Oving "Criminalisation of the ship's master and his crew" (2012) Kalmar Maritime Academy, Linnaeus University at 5 .

7 Oving, above n 6 , at 5 .

8 The ITWF highlights eight ships as evidence of this claim: Million Hope, Orapin Global, Erika, Asian Liberty, Amorgos, Prestige, Tasman Spirit and Celine. See International Transport Workers' Federation, above n 1, at 29. I have identified eight others to add to this non-exhaustive list of criminal maritime cases which have garnered high profile media attention: Aegan Sea, Nissos Amorgos, Tropic Brilliance, Zim Mexico II, Hebei Spirit, Full City, Asian Forest and Nordlake. See Hare, above n 6, at 3-4; Olivia Murray "Criminalisation of Seafarers - Recent Developments: Presentation to the international Working Group on the Fair Treatment of Seafarers" INCE and Co. at 4; Nautilus International "Criminalisation of seafarers" <http://content.yudu.com/Library/A1vef6/Criminalisationofsea/resources/index.htm?referrerUrl= http\%3A\%2F\%2Ffree.yudu.com\%2Fitem\%2Fdetails\%2F466362\%2FCriminalisation-ofseafarers\%3Frefid\%3D44870> (2011) at 11; and Oving, above n 6, at 11.
} 
seafarers include oil pollution outside of the control of the Master (Erika); ${ }^{9}$ grounding due to bad weather (Full City); ${ }^{10}$ a ship sinking after being refused refuge by a coastal state for salvage (Prestige); ${ }^{11}$ grounding of a vessel under pilot control (Tasman Spirit);12 running aground due to unknown underwater bank collapses (Nissos Amorgos); ${ }^{13}$ a containership knocking over a port crane (Zim Mexico III); ${ }^{14}$ a tanker being hit by an out of control crane barge (Hebei Spirit); ${ }^{15}$ and violations relating to the oily water separator (Celine). ${ }^{16}$ All of these incidences had varying degrees of criminality associated with seafarers. Many involved seafarers being held for extended periods, eventually leading to high profile criminal cases, and a number of these cases required lengthy appeal processes to apportion blame correctly. ${ }^{17}$ Part V of this paper will apply hypothetical scenarios based on four of these cases to the current NZ legislative framework and postulate what would happen in a 'worst case' scenario under NZ law.

\section{$B$ International response and impact}

The international legal community has taken note of the overwhelming damage caused by pollution spills and has agreed various conventions to which states can accede. There are two conventions that have particular impact on this criminalisation discussion: the Protocol Relating to Intervention on the High Seas in Cases of Pollution by Substances other than Oil ("MARPOL") ${ }^{18}$ and the United Nations Convention on the Law of the Sea ("UNCLOS"). ${ }^{19}$ MARPOL - short for marine pollution - is designed to minimise pollution accidents by regulating the passage of

\footnotetext{
${ }^{9}$ Hare, above n 6, at 3.

10 Nautilus International, above n 8, at 11; and Hare, above n 6, at 4.

11 Nautilus International, as above, at 10; Hare, above n 6, at 3; and Murray, above n 8, at 13.

12 Hare, above n 6, at 3.

13 Oving, above n 6, at 5-6.

14 At 8.

15 Nautilus International, above n 8, at 9-10; and Hare, above n 6, at 3-4.

16 Hare, above n 6, at 7.

17 Murray, above n 8, at 4.

18 Protocol Relating to Intervention on the High Seas in Cases of Pollution by Substances other than Oil 1313 as modified by the Protocol of 1978 UNTS 1 (entered into force 30 March 1983) [hereinafter referred to as "MARPOL"].

19 United Nations Convention on the Law of the Sea 1833 UNTS 3 (opened for signature 10 December 1982, entered into force 16 November 1994) [hereinafter referred to as "UNCLOS"].
} 
oil, dangerous goods, and harmful substances. Importantly, accidental spills do not violate MARPOL; there is no criminal liability for pollution or spills unless there is an intent or recklessness by seafarers, only prohibitions relating to the deliberate discharge of oil. ${ }^{20}$ MARPOL ensures that the laws of coastal states punish natural and legal persons "by effective, proportionate and dissuasive criminal penalties." 21 Part XII of UNCLOS gives coastal states the ability to adopt reasonable domestic measures to prevent pollution in their territorial waters. ${ }^{22}$ In their EEZ, states may adopt such laws if they are in conformity with, and give effect to, international rules and standards. ${ }^{23}$ This means that states are welcome to go further than the minimum standards when translating MARPOL and UNCLOS into their national laws.

States frequently extend the protections afforded under MARPOL and UNCLOS in the area of pollution. The extreme example is in European Union ("EU") legislation where the master, together with the owner, is criminally liable for an infringement if a discharge of oil occurs with intent, recklessness or serious negligence. ${ }^{24}$ EU legislation also imposes criminal sanctions for intentional, reckless, or seriously negligent ship-source pollution on any person who contributes to pollution, which in practice would most likely cover seafarers. Penalties range from significant fines - $€ 150,000$ to $€ 1,500,000$ - to imprisonment of up to five years. ${ }^{25}$ This legislation is enforceable against all ships calling at EU ports. ${ }^{26}$

\footnotetext{
20 For a summary see Nicola Giovannini and others "Addressing Environmental Crimes and Marine Pollution in the EU” (2013) Droit au Droit, Brussels at 9-12.

21 Articles 8, 8a, 8b and 8c of Directive 2005/35 [2005] OJ L 255.

22 See Articles 192, 194, 211, 217 and 218, Part XII of UNCLOS. For a summary, see Giovannini, above n 20 , at $12-14$.

23 The exclusive economic zone (the "EEZ") extends to 200 nautical miles off the coast of a state. 24 See Council Framework Decision 2005/667/JHA [2005] OJ L 255/164; and Directive 2005/35 [2005] OJ L 255.

25 Mitroussi, above n 1, at 1047; and Marc Huybrechts "Criminal Liability of Master and Crew in Oil Pollution Cases" in Michael Faure, Han Lixin and Shan Hongjun (eds) Maritime Pollution Liability and Policy: China, Europe and the US (Kluwer Law International, The Netherlands 2010) at 220. Some states go further than this EU standard. For example, French law has individual penalties for the worst kind of intentional pollution acts of up to $€ 15$ million and 10 years' imprisonment: North P\&I "France hits polluters hard" (April 2009) Signals Newsletter <www.nepia.com> at 5. 26 Mitroussi, above n 1, at 1047.
} 
The supporters of these types of criminal legislative instruments targeting maritime participants claim that such measures are necessary to improve maritime safety, but, as stridently argued by opponents, these regulations correspondingly have significant flow on effects. ${ }^{27}$ This is particularly true in the EU post-MARPOL primarily due to the size and reputation of the maritime industry but effects individuals enormously. The European Economic Union ("EEU") ${ }^{28}$ alone sees over 3.5 million tonnes of cargo annually transported on ships and EEU ship-owners control $40.8 \%$ of the global fleet measured in gross tonnage. ${ }^{29}$ Europe is also a high employer of seafarers making this criminalisation discussion particularly relevant. ${ }^{30}$

It is also important to remember that criminal law is inherently personal and penalties generally work best against individuals rather than organisations. ${ }^{31}$ Because the events giving rise to criminal liability in maritime law are often high profile and may involve vast property loss and personal damage, seafarers may become political scapegoats and be the target of undesirable outcomes. Seafarers are naturally reluctant to be held accountable for actions outside of their control; seafarers may become political hostages: “... seafarers might easily become the scapegoats as they are the ones who tend to be readily identified and primarily exposed to media and public criticism." 32

Reputational damage of seafarers is also a discernible outcome of criminal cases. ${ }^{33}$ This can have wellbeing and health effects, as occurred in the United States when the chief engineer of Celine, Ivan Peykoc, committed suicide on-board after the authorities started investigating suspected violations relating to the oily-water separator. ${ }^{34}$ Industry concerns link such pressure to the lessening of seafarers

\footnotetext{
27 At 1043; and International Transport Workers' Federation, above $\mathrm{n} 1$.

28 The EEU is the EU plus Norway, Iceland and Liechtenstein.

29 See Mitroussi, above n 1, at 1043.

${ }^{30}$ Greece is the biggest employer (both Greek registered ships and Greek owned vessels) with around 31,000 seafarers employed with another 11,000 working onshore. Mitroussi, above n 1, at 1045.

31 At 1043.

32 At 1047.

33 As Erika's Captain Karun experienced: See Part V Section Ba.

${ }^{34}$ Hare, above n 6, at 7; and Joe Brady Stamford "Stalemate in 'Celine' saga” (18 August 2005)

TradeWinds <http://www.tradewindsnews.com>.
} 
seeking employment in the industry: "although overall employment in the maritime business in Europe is stable, the number of European seafarers is declining ..."35

\section{Penalties}

As evident in the infamous cases identified above and in more detail in Part V, these types of criminal cases can take many years to resolve and have substantial imprisonment sentences and/or fines attached to such incidents, particularly involving pollution. Industry spokespeople also report that such public attention and scrutiny results in unreasonably high criminal sanctions. ${ }^{36} \mathrm{~A}$ recent example of this the Korean ferry, Sewol, which sunk in April 2013 killing 300 crew and passengers. This was a terrible tragedy with a high death rate for which the Master, Lee Joonseok, received a 36-year prison term after being found guilty of negligence for failing to organise evacuation efforts and also leaving the ship before the passengers. ${ }^{37}$ Industry defenders believe that this is the most recent example of seafarers being used as pawns in a political game; that the drive to criminalise the behaviour of the seafarers was unjust for the rest of those in the maritime industry. ${ }^{38}$ The Captain was not found guilty of murder (or any other wrongful death charge) yet received an extreme sentence. On the other hand, the chief engineer of Sewol, Park Gi-ho, was found guilty of murder and sentenced to a lesser sentence of 30 years. Thirteen other crewmembers currently face imprisonment sentences between five and 20 years. ${ }^{39}$

Arguably, unlike the preceding examples, Zim Mexico III is a suitable case for criminalisation of a seafarer. In one of the rare high profile cases not involving pollution, a container ship knocked over a crane in Mobile, Alabama when her

\footnotetext{
35 Mitroussi, above n 1, at 1043.

36 David Osler "Sewol jail terms too harsh, say seafarer organisations" (20 November 2014) Lloyd's List Australia 9 at 9; and Gary Dixon "Top union slams severity of Sewol crew sentences" (14 November 2014) Lloyd's List Australia 7 at 7.

37 This is effectively a life sentence as Captain Joonseok was aged 69 at the time of the incident. See Osler, as above, at 9; and Dixon, as above, at 7.

38 Osler, as above, at 9; and Dixon, as above, at 7.

39 Osler, as above, at 9; and Dixon, as above, at 7.
} 
bowthruster failed when exiting the port. ${ }^{40}$ The shoreside crane fall crushed and killed electrician, Shawn Jacobs, who was working on the crane in March 2006. ${ }^{41}$ The German Master of Zim Mexico III, Captain Schroeder, was arrested for contravening seaman manslaughter legislation in the United States. ${ }^{42}$ The Master agreed a plea bargain from manslaughter to simple negligence and was released 11 months after the incident for time served. ${ }^{43}$ The Captain was acting within the scope of his duties at the time of the incident and he should have to take responsibility for the malfunction of the bowthruster. This case also indicates also that criminalisation of seafarers is not limited to Europe nor to pollution cases.

\section{Jurisdictional challenges}

A factor of the maritime industry is the collision of various jurisdictions and laws. Seafarers contend with multiple jurisdictions - the flag state, coastal or port state, and the seafarer's state of nationality. ${ }^{44}$ The Prestige case highlights this global reach: Prestige's owners (Mere Shipping) were located in Greece and Liberia; she was flagged in the Bahamas; was in class with the American Bureau of Shipping; was chartered by a Swiss-based Russian company (Crown Resources) from their London office; was crewed by mainly Greek and Filipino seafarers; was sailing from Latvia to Singapore; and sunk off the coast of Spain..$^{45}$ This global reach is an important trait

\footnotetext{
40 Oving, above n 6, at 8; and Michael Chalos and Eugene O'Connor "The ZIM Mexico III incident and the trial of Captain Schroeder - The complete saga" (1 August 2007) Grad News

$<$ http://www.gard.no>.

${ }^{41}$ Oving, above $\mathrm{n} 6$, at 8 ; and Chalos and O'Connor, as above.

42 The owner of the vessel was also charged as being vicariously liable for the Master's actions. Chalos and $\mathrm{O}^{\prime}$ Connor, as above.

43 Oving, above $n 6$, at 8 .

${ }^{44}$ See Giovannini, above n 20, at 5-6; Yvonne Baatz (ed.) Maritime Law (3rd ed, Routledge, New York, 2014); Alla Pozdnakova Criminal Jurisdiction over Perpetrators of Ship-Source Pollution (Martinus Nijhoff Publishers, The Netherlands, 2012) at 2-5; and Michael Tsimplis "Shipping and the Marine Environment in the 21st Centry" in Malcolm Clarke (ed.) Maritime Law Evolving: Thirty Years at Southhampton (Hart Publishing Ltd, United Kingdom, 2013) at 106-112.

${ }^{45}$ Nautilus International, above n 8, at 10; and "Prestige oil tanker disaster crew acquitted in Spain" (13 November 2013) BBC <http://www.bbc.co.uk>. The Erika case also highlights this multijurisdictional point: Permanent Commission of Enquiry into Accidents at Sea "Report of the enquiry into the sinking of Erika off the coasts of Brittany on 12 December 1999" Permanent Commission of enquiry into accidents at sea <http://www.beamer-france.org/BanqueDocument/pdf_87.pdf $>$ at 911.
} 
of the maritime industry. ${ }^{46}$ This multi-jurisdictional puzzle is confusing and is an intimidating and daunting problem for seafarers that workers in other industries do not generally have to grapple with. ${ }^{47}$ Often seafarers who are caught up in criminal action will not be nationals of the state where the incident occurs; prior knowledge of the law is difficult to assume in such cases. ${ }^{48}$ Michael Lund, BIMCO's Chief Shipping Policy and Economics Officer, reiterated this in an industry speech: ${ }^{49}$

... seafarers may be prosecuted in a wide range of jurisdictions for a wide range of offences and under a number of laws, which make it virtually impossible for the individual seafarer to have knowledge of the criminal risks associated with a given action.

NZ's maritime laws make up one part of this international jurisdictional discussion. This paper now will discuss NZ legislation to determine whether NZ is following international trends promoting criminalisation of seafarers. NZ has had few prosecutions in this area so the reality might be different in practice but the potential is located in the criminal source law.

\section{New Zealand maritime industry}

Given its geographic isolation, NZ has always been dependent on shipping. NZ, as a country, also places emphasis on the protection of the physical environment and taiao (natural world), including tai (the sea) and papamoana (the seabed). ${ }^{50}$ This means that this jurisdiction has a stake in maintaining environmental controls in, and on, the sea. While there are no merchant ships currently flagged under NZ

\footnotetext{
46 For example, that EU sanctions apply “...irrespective of the flag, which the vessel would fly, and the Directive is applicable starting from internal waters, to territorial seas and into the high seas. The sanctions have to apply to the owner, the master, the crew, the salvour, the charterer and the classification society, in other words, everyone who is connected with the incident and shares some responsibility for the incident": Huybrechts, above n 25, at 221.

47 International Transport Workers' Federation, above n 1, at 32.

${ }^{48}$ Michael Lund "Speech for International Seminar of Russian Register of Shipping 22-23 October 2008 Quality Shipping: XXI Century Standard. Seafaring Careers: Raising the Profile" (20 October 2008) at 4.

${ }^{49}$ As above.

${ }^{50}$ See as examples: section 4 of the Marine and Coastal Area (Takutai Moana) Act 2011; section 5 of the Resource Management Act 1991 [hereinafter referred to as the "RMA"]; and section 10 of the Exclusive Economic Zone and Continental Shelf (Environmental Effects) Act 2012.
} 
law that regularly operate on international routes, various shipping companies operate in NZ - in 2013, fishing company Sanford Limited had 51 vessels. ${ }^{51}$ Merchant ships from all around the world visit NZ's waters and ports on a daily basis and thus this discussion is relevant.

While it has been argued that NZ has "one of the least regulated shipping regimes in the world",52 this is not true in practice. NZ has a history of comprehensive regulation in the maritime industry and there are two main pieces of legislation in the past sixty years: the Shipping and Seamen Act 1952 ("SSA") and the MTA. The SSA came into force on 19 November 1953. By the time it was repealed on 1 February 1995 it was very different from what was enacted forty years earlier. The SSA was the focus of considerable amendments which made this statutory instrument lengthy, but also made it difficult to reconcile what summary offences or indictable crimes each penalty would attach to. Such amendments to the SSA reflected global changes in workers and employees rights; technological advancements; and an increasing amount of international obligations particularly in protection of environments in the late 1980s. The SSA ended up as a mixed bundle of rights and responsibilities as a mixed and incomprehensible bundle, so by the early 1990s there was a push for a more cohesive Act.

Of note, the SSA contained a catch-all provision whereby if the Act states a "crime" 53 and there is no special penalty attached, then that person shall be liable for imprisonment not exceeding two years and/or a fine not exceeding $\$ 1,000.54$ There is also a comparable section regarding an "offence" 55 whereby the penalty is a fine not exceeding $\$ 1,000$, unless a special penalty is provided in the section, ${ }^{56}$ with a continuing fine of $\$ 50$ per day for which the offence continues. ${ }^{57}$ The MTA is much clearer here and reflects the evolution of legislation so that crimes are seen as more

${ }^{51}$ Sanford Limited "Health and Safety Reform Bill Sanford Limited Submission" (7 May 2014) at 2.

52 Gareth Hughes (Green) (11 September 2012) 683 NZPD 5080.

${ }^{53}$ Section 479 of the Shipping and Seamen Act 1952 [hereinafter referred to as the "SSA"].

54 Section 479.

55 Section 480 .

56 Section $480(2)$.

57 Section $480(3)$. 
serious (such as murder and sexual offences under the Crimes Act 1961) and offences less serious (such as trespass under the Summary Offences Act 1981 and the possession of controlled substances under the Misuse of Drugs Act 1975). This is clarification evident in the cohesive drafting in the MTA.

The MTA was first introduced to the House of Representatives as the Transport Reform Bill on 5 May 1993.58 The part of the Bill dealing with the maritime industry eventually evolved into the MTA - replacing the outdated SSA alongside an Act regulating the civil aviation industry. ${ }^{59}$ The MTA applies to all NZ ships wherever they may be. ${ }^{60}$ The MTA also replaced the Marine Pollution Act 1974 ("MPA").

A particular focus of this current Act is implementing NZ's obligations under international law (particularly conventions relating to pollution of the marine environment); ensuring that participants in the maritime transport system are responsible for their individual actions; and protecting the natural environment. ${ }^{61}$ These are the overriding principles of the MTA pivotal to this discussion of criminalisation. Importantly, most of the offences that appeared in the SSA are provided for in the MTA if they are still relevant in today's age, albeit in updated 'new' language and are often stated in terms that are more general. For example, there are no longer specific provisions relating to the engagement of illegal workers/aliens or the carriage of grain and flax, as these are largely irrelevant and are covered by general MTA obligations.

There are three categories of seafarers to which criminal liability can attach to under the MTA. These definitions are provided in section 2 and are summarised as follows: ${ }^{62}$

- "Seafarer" is the general term for any person who is employed or engaged on a ship in any capacity for reward or for hire.

\footnotetext{
58 Maritime Transport Bill 1993 (select committee report) I.13A at 2.

${ }^{59}$ Civil Aviation Act 1990.

60 Section 4(4) of the MTA.

61 Preamble (b), (c), (f) and (g).

62 Note that all three definitions contained in section 2 of the MTA exclude pilots.
} 
There are then two subsets of seafarers:

- The "master", being the person having command or charge of a ship (for identification purposes, masters will generally have the title of 'Captain'); and

- "Crew" who are all other seafarers employed or engaged on a ship other than the master.

Some provisions of the MTA are drafted so that offences apply to "any person" or "every person" which encompasses all seafarers. However, the majority of offences in the MTA target the master as the person in charge of the ship at the time the offence was committed.

\section{Criminal responsibility}

This paper will examine several areas of responsibility where seafarers are liable under domestic law. I have placed these into five categories of offences for this discussion: (a) health and safety; (b) emergencies, collisions, or accidents; (c) employment rights and obligations; (d) financial and regulatory responsibilities; and (e) administration of justice. Every maritime offence and crime in NZ legislation has been reviewed in this analysis. In undertaking this examination, it is evident that the main area of increasing criminalisation for seafarers is in relation to pollution offences. These offences particularly affect masters.

\section{A Health and safety}

Health and safety offences in the maritime industry span several legislative instruments but have remained mostly constant through NZ's history, except for pollution offences (particularly for dangerous or hazardous cargo). ${ }^{63}$ This area is heavily influenced by international obligations and is an active and live issue in NZ, particularly in light of the recent 2012 amendment Bill whereby NZ acceded to the

\footnotetext{
63 This paper will not discuss sections 60, 62 and 63 of the MTA as repelled by section 35(1)(d) of the Health and Safety in Employment Amendment Act 2002. I focus on the current offences expressly relating to seafarers.
} 
1973 Protocol Relating to Intervention on the High Seas in Cases of Pollution by Substances other than Oil. ${ }^{64}$ There are still weaknesses in acceding international conventions relating to deliberate and accidental pollution acts - for example, NZ has not acceded to all annexes of MARPOL. ${ }^{65}$ Despite this gap, and as expected, there are numerous provisions relating to pollution in the MTA. Of note is that responsibility for the compliance of the vast majority of these provisions lies with the master rather than the crew. The current provisions relating to dangerous cargo go further than was provided for in the SSA and MPA. This is expected and reasonable given the vast impact - politically and environmentally - of pollution cases. Interestingly, there were no comparable offences in previous legislation regarding hazardous cargo. These types of situations, together with pollution and oil spills, would have fallen under all-purpose health and safety requirements of the SSA, particularly pertaining to dangerous goods or unseaworthiness. This area of criminal responsibility shows that these new offences are a product of the evolving nature of the maritime industry and education lessons from past disasters.

There are also some new broad offences relating to health and safety - such as safety equipment and wellbeing of crew. Most of these offences will in practice apply to masters only, as they have control of the ship and crew, though the offences are commonly expressed as applying to all persons.

\section{a. Dangerous/hazardous cargo}

There is a general offence for breaching any MTA requirement when carrying dangerous goods. ${ }^{66}$ This is in contrast to the SSA's particular rules and offences relating to the carriage of grain; ${ }^{67}$ livestock; ${ }^{68}$ wool; flax; tow; skins; or other goods liable to spontaneous combustion; ${ }^{69}$ and unpermitted deck cargo. ${ }^{70}$ The MTA does

\footnotetext{
${ }^{64}$ Protocol Relating to Intervention on the High Seas in Cases of Pollution by Substances other than Oil, above n 18.

${ }^{65}$ This was stated during the Bill's debate by a Green Party Member of Parliament: See Denise Roach (Green) (11 September 2012) 683 NZPD 5080.

${ }^{66}$ Section $67 \mathrm{~B}(1)(\mathrm{b})$ of the MTA

${ }^{67}$ Section 309 of the SSA.

${ }^{68}$ Section $313 \mathrm{~A}(4)$.

${ }^{69}$ Section 311(2).
} 
not go into this amount of detail though the Director of MNZ ("Director") can seize, or impose conditions on, ships or products if there are issues of endangerment.; ${ }^{71}$ Seafarers are protected from prosecution if they are not "familiar with essential shipboard procedures for the safe operation of the ship."72

Only a master can be liable for the discharge or escape of hazardous substances into the sea or seabed. ${ }^{73}$ This is an overarching clause and shares the most severe penalty under the MTA (with insurance offences) being imprisonment of up to two years or a fine not exceeding $\$ 200,000.74$ Alongside this general obligation of the master, lie more specific obligations: The master is the only seafarer who can commit the offence of failing to report harmful discharge; ${ }^{75}$ failing to notify incidents of pollution; ${ }^{76}$ and failing to notify the arrival of a ship carrying oil or noxious liquid substances or the transfer of such substances. ${ }^{77}$ The master is likewise liable for a fine of up to $\$ 200,000$ if they store hazardous waste in the sea or on the seabed..$^{78}$ Correspondingly, if waste is taken onto a ship with the purpose of being dumped (or is dumped), an offence is committed which the master is liable for with the same penalties. ${ }^{79}$ Any person who exports waste for dumping or incineration is liable for an offence with the same penalties. ${ }^{80}$ This could extend to seafarers who may have knowledge of dumping before it occurs or who may be operating under the (unlawful) direction of the master or others in authority.

It was previously an offence under the MPA whereby the master was liable for any pollutant if it was discharged or escaped into NZ waters or was dumped. ${ }^{81}$ There

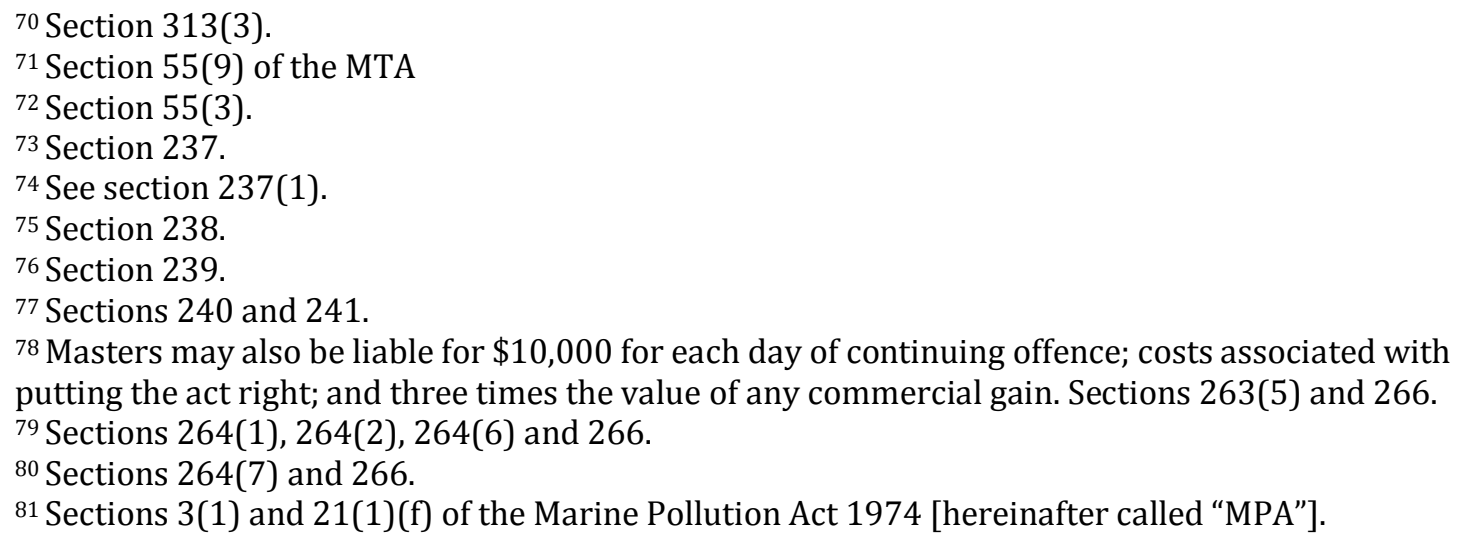


was a comparable offence for NZ ships outside of NZ waters. ${ }^{82}$ Limited defences were available to the master, such as for preventing damaging to the ship or her crew, or if the discharge occurred due to major structural damage. ${ }^{83}$ The penalty for breaching these sections was a $\$ 50,000$ fine and in the case of waste dumping they were liable for clean-up costs too. ${ }^{84}$ It was also an offence to transfer oil or pollutants to or from any ship in a NZ harbour without the correct notice (unless the fire brigade was supervising) punishable against the master of a fine not exceeding $\$ 3,000.85$

The MTA also introduces the concept of maintaining maritime documents, including the requirement for seafarers to be certified as fit and proper persons. ${ }^{86}$ Any person holding a maritime document who causes unnecessary danger to persons or property, irrespective of whether the damage or injury eventuates, commits an offence. ${ }^{87}$ They also commit an offence if they operate, maintain or service anything on a ship or product which causes unnecessary damage to persons or property. ${ }^{88}$ Hefty penalties attach to these criminal safety breaches whereby individuals are liable for up to 12 months imprisonment or a fine of up to $\$ 10,000$ for each day of delay. ${ }^{89}$ Individuals can also be disqualified from holding maritime documentation, or imposition of conditions on documentation. ${ }^{90}$ This affects seafarers as they will hold appropriate documentation and may impact their certification prospects in the fit and proper person category.

This area of criminality was highlighted in NZ after the grounding of Rena in 2011 as discussed in Part V(A).

\footnotetext{
${ }^{82}$ Section 4(1).

${ }^{83}$ Sections 6(1) and 6(2).

${ }^{84}$ Sections $10(a)$ and $21(2)$.

${ }^{85}$ Section 14.

${ }^{86}$ Maritime New Zealand "Fit and proper person check" <www.maritimenz.govt.nz>.

${ }^{87}$ Section $64(1)$ of the MTA.

${ }^{88}$ Section 65(1).

${ }^{89}$ Individuals are also liable for three times the value of any commercial gain. Section 64(1).

${ }^{90}$ For a breach of sections 65(1) or 65(2): see Section 73(1).
} 


\section{b. Marine protection documentation}

New to the MTA regime, is the requirement to hold the current and necessary marine protection documents. These documents outline standards for carrying oil and noxious liquid substances as prescribed by MARPOL and other international regulations after the cases involving vast international damage. Any person is liable for a criminal offence if they act without necessary documentation; ${ }^{91}$ act in breach; ${ }^{92}$ or if they know that a current document is required for an act to be lawfully undertaken, ${ }^{93}$ even in emergencies. ${ }^{94}$ It is an offence for any person to fail to comply with an audit or inspection by the Director, or when detaining or seizing products relating to such documentation without reasonable excuse. ${ }^{95}$ This would capture seafarers who are travelling on a ship which is required to have such documentation, but it is questionable whether crew would have the requisite knowledge whether documentation was current. In any event, in practice the burden of this offence would likely fall with the master as he would be the person with the knowledge.

\section{c. Notifications and investigations of oil spills}

Seafarers have a current obligation to (a) notify the Director or regional council of the inability to contain or clean-up a marine oil spill and (b) follow the Director's instructions, or they are guilty of an offence. ${ }^{96}$ The comparable requirement appeared in the MPA whereby it was the duty of the master to report discharges punishable by a fine of up to $\$ 10,000.97$ It is questionable whether seafarers would know that notification has taken place, however it is a reasonable public policy consideration to ensure that such spills are notified effectively.

Of note, every person commits an offence if they disobey instructions relating to the protection of the marine environment, or wilfully obstructing others from

${ }^{91}$ Sections 277(1) and 279.

${ }^{92}$ Sections 278 and 279.

${ }^{93}$ Sections 277(2), 279 and 280.

${ }^{94}$ Section 403(2).

${ }^{95}$ Sections 402 and 403(1).

${ }^{96}$ Sections 253(4) and 317.

${ }^{97}$ Section 16 of the MPA. 
acting in compliance of such instructions, or obstructing the Director in their duties. $^{98}$ This obstruction comes with a high penalty of up to two years imprisonment or a fine not exceeding $\$ 200,000$, with $\$ 10,000$ for each day of delay of compliance. Individuals can only be imprisoned if they had the mandatory knowledge to intend to commit the offence or was reckless to the act and if the offence caused, or was likely to cause, serious damage to the marine environment. This shows the importance that the marine environment has on this current legislative framework in NZ.

Seafarers have general obligations in this area and non-compliance with these obligations is an offence:

- Every person who, without reasonable cause, fails to comply with an investigation relating to pollution commits an offence and is liable for a fine not exceeding $\$ 1000 .{ }^{99}$ Reasonably, a seafarer may be called to give evidence or reproduce information as part of an investigation and if they refuse, they will be held criminally liable. This offence could stretch to other people outside the industry, such as family members or government officials.

- If the Director issues a requirement to rectify hazardous conditions; to take precautionary measures in the event of oil or noxious liquid substances; or to provide reception facilities, then every person must follow these directives. ${ }^{100}$ Each violator faces a fine of $\$ 10,000$ and $\$ 2,000$ per day of non-compliance. ${ }^{101}$

- Every person must abide by prohibitions in relation to transferring oil or noxious liquid substances or face a fine not exceeding $\$ 5,000$ and $\$ 1,000$ for each day of delay. ${ }^{102}$ These offences apply to both crew and master.

\footnotetext{
${ }^{98}$ Sections 253, 253(1), 253(4) and 253(5) of the MTA.

${ }^{99}$ Section 235(6) of the MTA.

${ }^{100}$ Section 242.

101 Section 244(3).

102 Sections 242A and 245.
} 


\section{d. Health and wellbeing of crew}

The master of any ship approaching NZ is responsible for ascertaining the state of health of each person on board under section 102(1) of the Health Act 1956. Upon arrival, the master has to deliver a health declaration to the correct authorities. ${ }^{103}$ If the master fails to do so then he commits an offence and is liable for a nominal fine not exceeding $\$ 1,000,104$ or $\$ 2,000$ if the master deceives or otherwise influences others under this section. ${ }^{105}$ In most cases, this will be the responsibility of the operator of the ship so the offence targets the master's role. This area of criminal responsibility was comprehensive in the SSA. For example, the every person was liable if they breached the requirement to procure the services of a doctor as soon as possible after an on-board injury. ${ }^{106}$ The master was responsible to providing a supply of medicines - "antiscorbutics"107 - and medical handbooks. ${ }^{108}$ Every person who manufactured, sold or kept any medicines for use on board a ship that were of bad quality or deficient in strength committed an offence. ${ }^{109}$ The master also had a requirement under this SSA to provide suitable, clean, habitable, and serviceable accommodation for crew that was not used for any other purpose. ${ }^{110}$

\section{e. Number of seafarers}

In the MTA anyone who breaches the regulations for operating a ship without the required number of seafarers or qualified personnel commits an offence. ${ }^{111}$ This offence was similarly outlined in section 55(6) of the SSA but more detailed, such as a ship cannot proceed to seas with less than four-fifths of the total persons on deck or engine room otherwise the ship faced detention. ${ }^{112}$ The SSA also states that, unless there is an emergency, crew cannot be employed in another capacity than

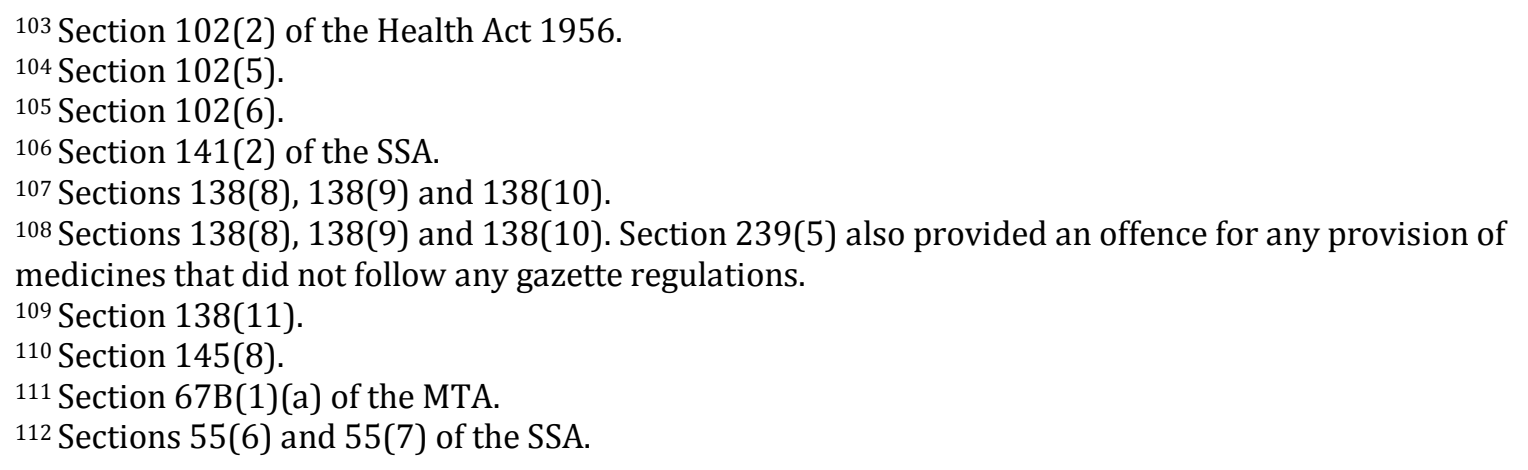


what they entered on-board, ${ }^{113}$ and provides the rules for vessels under towage. ${ }^{114}$ Once again, in practice these offences will apply against masters as they are in charge of their vessel.

\section{f. Load lines}

It is an offence under the MTA if any person allows the ship's load lines to submerge when proceeding to sea, during a voyage, or at a ship's arrival to port. Hefty penalties attach to these criminal breaches whereby individuals are liable for up to 12 months imprisonment or a fine of up to $\$ 10,000$ for each day of delay. ${ }^{115}$ All participants in the maritime industry could be liable - from seafarers on board to workers loading the ships. This is a new provision in the 2012 amendment reforms and was slightly different than provided for in the SSA. ${ }^{116}$ Under the SSA, the master was guilty of an offence for failing to have a correct load line certificate; if the load line was incorrectly marked on the ship; ${ }^{117}$ or for the markings were not maintained. 118 Any person was guilty of an offence if they concealed; removed; altered; defaced; or obliterate a load line mark (or permits another person to do so). ${ }^{119}$ The master was responsible for framing and displaying the load line certificate. ${ }^{120}$

There has evolved a concern for vessels carrying iron sand particularly from Port Taharoa on the west coast of the North Island between Hamilton and Auckland under these MTA provisions. The justification for this strict adherence to load lines is given that even a small allowance and discretion over the load lines can represent thousands of tonnes of overload. This is unsafe if conditions change and thus

\footnotetext{
113 Section 55(9).

${ }^{114}$ Section $55 \mathrm{~A}(5 \mathrm{~A})$.

115 Individuals are also liable for three times the value of any commercial gain. Section $67 \mathrm{~A}(1)$ of the MTA.

116 Ministry of Transport and Ministry for the Environment Marine Legislation Bill 2012: Report of the Ministry of Transport and the Ministry for the Environment (2012) at 72.

117 Subject to a fine of $\$ 10,000$ : See Section 262(2) of the SSA.

118 Subject to a fine of $\$ 10,000$ : Section $264(1)$. Similar obligations for submersion load lines as well: see sections $270(15)$ and $270(16)$.

119 Section 264(2).

120 Section 262(2).
} 
everyone involved has a responsibility to monitor this position. ${ }^{121}$ Once again, it is reasonable that the practical burden of these obligations will fall to the person operating and in charge of the vessel: the master.

\section{g. Safety items and surveying of ships}

There were historical provisions relating to safety equipment and surveying of ships; there are no comparable provisions in the MTA. The legislation went into detail about what is required including such as anchors and chain cables; ${ }^{122}$ navigational equipment; ${ }^{123}$ safety equipment; ${ }^{124}$ radio equipment; ${ }^{125}$ automatic pilot and testing of steering gear; ${ }^{126}$ and hull openings and water tightness. ${ }^{127}$ Punishments for failing to comply with safety equipment requirements were steep: a fine of $\$ 1000$ and a continuing further amount of $\$ 100$ for each day of noncompliance. There were also obligations in the SSA regarding surveying, ${ }^{128}$ and the notice and carrying out construction work on ships. ${ }^{129}$ The surveyor yielded power under the SSA and MPA and it was an offence against the master if the ship sailed without surveyor certification that the ship had passed requirements; ${ }^{130}$ or if the master failed to produce the certificate for customs or an authority. ${ }^{131}$ If the surveyor requested information on the ships age, tonnage, fuel and capacity, every person was liable for an offence if this information was not given; ${ }^{132}$ though in

\footnotetext{
121 Ministry of Transport and Ministry for the Environment, above n 116, at 74 .

122 Sections 233, 300 and 301 of the SSA. There are two particular offences whereby the master is liable for using an uncertified, untested anchor that may be displaying a fake distinctive mark. Every person (but in practice, manufacturers) was liable for an offence if they false mark an anchor under section 302(2),

123 Section 234.

124 Section 235.

125 Section 236.

126 Section 237.

127 Section 238.

128 Section 210.

${ }^{129}$ Sections 196(5), 197(g), 198(4) and 199(2).

130 Sections 208(2) and 220(5). It was also an offence against the master if there was more than one certificates for a ship and the logbook did not state, at the start of the voyage, which certificate the ship was sailing under: see section 223(3). See also sections 7(4) and 8(4) of the MPA.

131 Sections 208(3) and 220(7) of the SSA.

132 Section 209 of the SSA.
} 
practice this offence targeted owners and agents. Such certificates needed to be displayed and the master was liable for failure to do so. ${ }^{133}$

\section{h. Other offences}

There are a few additional health and safety related offences that carry penalties for non-compliant seafarers. These areas of responsibility are reasonably attributable to seafarers as they require knowledge or are role-related. Such offences carry imprisonment penalties for anyone breaching the regulations: for operating a ship outside its prescribed operating limits; ${ }^{134}$ knowingly breaching any requirement in the MTA for the carriage of dangerous goods; ${ }^{135}$ or acting without the necessary, appropriate, and current maritime documentation. ${ }^{136}$ It is also an offence to fail to comply with an audit request in relation to the holder of a maritime document or for the health and safety of seafarers. ${ }^{137}$ This latter offence can lead to disqualification of a maritime document or the position of conditions for up to 12 months. ${ }^{138}$

Generally the MTA offence provisions encompass a range of different scenarios. There are similar provisions in the preceding legislation however, once again, health and safety offences under the SSA are more specific in nature - for example detailing that the master is criminally liable if the ship does not carry current charts, directions, lighthouse notices, tide tables, or compasses. ${ }^{139}$ It was a particular offence under the SSA not labelling the nature of dangerous goods on the outside of package as well as on the same side as the address. ${ }^{140}$ Until 1987, it was also an offence against the master if the ship did not carry radar or an echo-

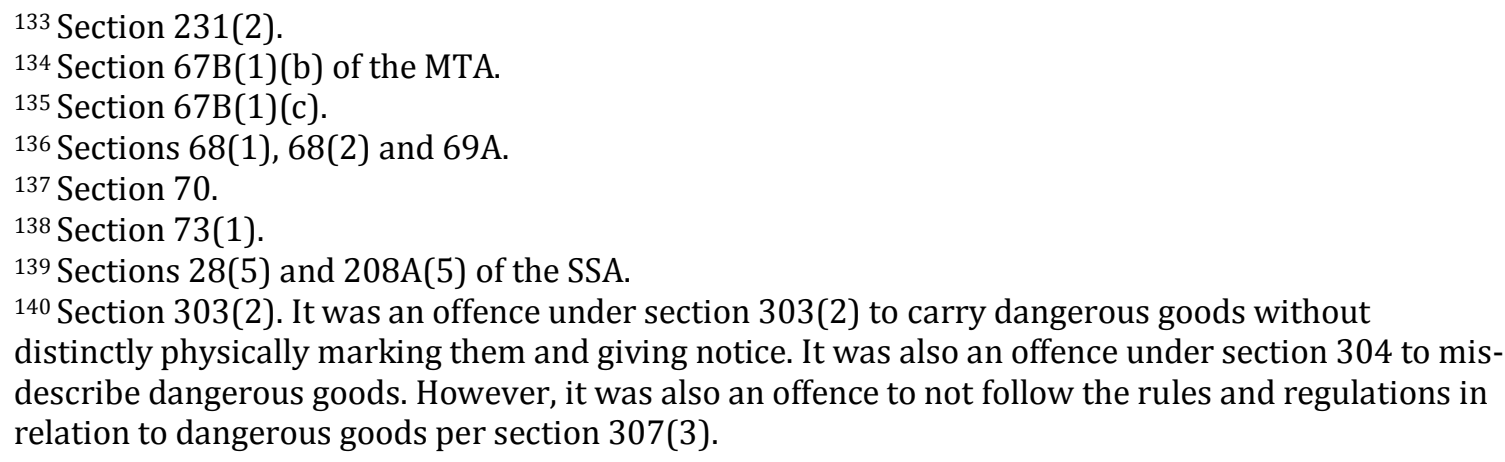
distinctly physically marking them and giving notice. It was also an offence under section 304 to misdescribe dangerous goods. However, it was also an offence to not follow the rules and regulations in relation to dangerous goods per section $307(3)$. 
sounding device ${ }^{141}$ and there were rules as to ballast. ${ }^{142}$ There were also large penalties which attached to piloting. ${ }^{143}$

\section{B Emergencies, collisions or accidents}

This area targets obligations after an accident in an emergency. The blame is apportioned, unsurprisingly, to those with the responsibility to control such acts onboard the ship. Both the MTA and SSA hold the master accountable for criminal offences relating to emergency situations, collisions or accidents.

\section{a. Emergencies}

Effectively the obligations on the master in emerges remain constant through the MTA and SSA. The MTA contains a general statement about following all directions and statutory obligations in the event of an emergency. The Master carries the burden of carrying out these obligations and if a master fails to perform their duties without reasonable excuse then they commit an offence. ${ }^{144}$ In an emergency, the master must notify the Director as soon as practically possible if they have to breach their duties in the interests of safety and must follow any emergency maritime rules. ${ }^{145}$ The SSA deals with collisions and emergencies and contains a whole raft of specific offences. For example, in the SSA the master was criminally liable for failing to obey collision regulations; ${ }^{146}$ falsely using distress signals; ${ }^{147}$ not reporting ice near the ship's course at night; ${ }^{148}$ and reporting unexpected dangers to navigations including hurricanes and other storms. ${ }^{149}$ There

\footnotetext{
141 Sections $210 \mathrm{~A}(6)$ and $210 \mathrm{~B}(6)$.

142 Section $310(3)$ of the SSA and section 11(d)(i) of the MPA. Offence was punishable by a fine not exceeding $\$ 3,000$ : section $11(7)$. 143 Sections 265(3) and 238A(2) of the SSA. Section 67(1) of the SSA outlines the penalties for individuals being up to 12 months imprisonment or a fine of up to $\$ 10,000$ with additional penalties being available the cost being three times the value of any commercial gain.

144 Section 19(4) of the MTA. The duties are outlined in section 19(1)(d) of the MTA.

145 Sections 19(4) and 38(1) of the MTA. The penalties for not obeying emergency rules are fines not exceeding $\$ 5,000$ for individuals: See section 38(1).

146 Section $287(2)$ of the SSA.

147 Sections 293(3) and (5).

148 Section 295(2).

${ }^{149}$ Section 296(2).
} 
were also specific requirements on the master to have warning devices, emergency illumination and means of egress for all persons, ${ }^{150}$ and displaying safety notices. ${ }^{151}$

Of note is the offence contained in the SSA that every person was guilty of a crime who sends a ship to sea that is unseaworthy and a threat of the life of any person. ${ }^{152}$ The master is also liable under a separate section. ${ }^{153}$ While this is wider than simply an emergency, it is clear that there is an element of reporting and selfinterest that is required by seafarers. The same issues crop up here in that they might not have the requisite knowledge to know that the ship has a problem that makes it a threat to life or they might be under an order to sail anyway. This is not replicated in the MTA although, though there is the generalist offence if anyone operates, maintains or services anything on a ship or product which causes unnecessary damage to persons or property. ${ }^{154}$ This is the comparable offence albeit worded differently.

\section{b. Answer distress calls and provide navigation assistance}

The master currently has an express duty to assist persons and ships in danger, to respond to distress calls and "shall proceed with all speed"155 to the assistance of persons and master in distress. ${ }^{156}$ The master also has a duty to assist persons in danger as far as they can do so without serious danger to their ship or persons. ${ }^{157}$ An offence is committed if the master of any NZ ship, or any ship in NZ waters, does not report to nearby ships any dangers to navigation including if a navigation aid is moved or displaced. This general offence relating to assistance also existed in the SSA but the penalties were less strict. Under current legislation the penalty of disobeying these sections is high: imprisonment not exceeding 12 months and/or a fine not exceeding $\$ 100,000$. This means that, if it is safe to do so, the

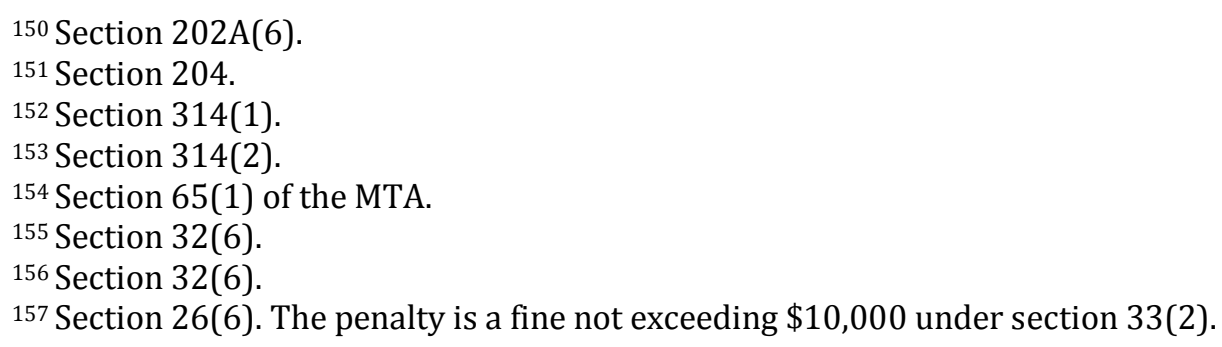


master currently must: respond fast to all distress calls unless they are informed that assistance is not required; assist any person found at sea; assist the ship, crew and passengers post-collusion; and, after a collusion, they must inform the other ship's master of the ship's name, port of register and the port it will sail to.

Under the SSA, the master had a duty to render assistance to the other ship and stay near unless it was ascertained that there was no need for further assistance. ${ }^{158}$ The master was also under an unambiguous obligation to take in seamen who were in distress and provide them with a bed or sleeping place protected against the sea and weather. ${ }^{159}$ The master committed an offence if they failed to assist persons in danger at sea; "even if that person is a subject of a State at war with Her Majesty"160 unless doing so would create serious danger to own ship or seafarers. In practice, there is no increased criminalisation in this area though the obligations are outlined differently in the legislation.

\section{c. Death or injury}

A master of a NZ ship, a foreign ship in NZ waters, or an operator of such ship must report any mishaps or accidents (including death or injury) as soon as practicable. ${ }^{161}$ Every person is liable for this offence of a fine up to $\$ 5,000^{162}$ though in practice it will only be those individuals with the respective responsibility (the master or second-in-command) rather than each individual without a role to play who have this burden. Similar provisions existed in the SSA whereby the master had to report any accident causing death or serious injury or effecting seaworthiness of the ship. ${ }^{163}$ This is no increased criminalisation in this area.

\footnotetext{
158 Sections 294(5), 294(7) and 289(2) of the SSA. All decisions had to be logged in the ship's logbook per section 290(2).

159 Section $130(3)$.

160 Section 292(1).

161 Section 71(1) of the MTA.

162 Section 71(1).

163 Sections 297(1) and 297(4) of the SSA.
} 


\section{Employment rights and obligations}

There are rules surrounding the employment of seafarers. These requirements have evolved over the past fifty years taking into account new international developments about youth labour and work quality. The MTA exhibits this trend towards employees' rights, but is mostly silent on the employment of seafarers; general employment law would capture most employment obligations. This is a significant change from the SSA where the master was criminally liable - and so was the chief engineer in certain circumstances ${ }^{164}$ - if crewmembers did not have an employment agreement. ${ }^{165}$ This was largely union driven and such collective agreements had to be conspicuously posted and displayed ${ }^{166}$ and delivered within the ship's arrival at port, ${ }^{167}$ presumably as evidence of such an agreement. Similarly, all crew changes had to be notified by the master to authorities. ${ }^{168}$ Any person, including seafarers, who removed, defaced or destroyed such displayed agreement, committed an offence. ${ }^{169}$ These prescriptive offences no longer exist.

\section{a. Age, nationality and skills}

Nationality restrictions do not exist. Previously, there were restrictions on the employment of aliens on ships as masters, first mates, or the chief engineer. ${ }^{170}$ There is no comparable section or offence in the MTA.

There are still age restrictions for the employment of seafarers however. In most cases, persons under the age of 18 cannot be engaged on a ship. 18 years old is the earliest someone can be employed as a trimmer or stoker unless reasonable steps have been taken; and it is an offence for employers of seafarers to neglect to keep a register of those seafarers employed under the age of $18 .{ }^{171}$ While this offence relates to an employer, in practice the master may be in charge of

\footnotetext{
${ }^{164}$ Section 47(4).

165 Sections 32(4) and 33(3).

${ }^{166}$ Section 36(2).

167 Section 35(2).

168 Section 45(4).

169 Section 36(3.

170 Section 17(A).

${ }^{171}$ Section $71(3)$ of the MTA.
} 
maintaining the on-board register. It was an offence under the SSA if the master did not maintain a list of crew, if someone under the age of 15 was employed, and if a seafarer under the age of 18 was not certified as fit for employment. ${ }^{172}$ Interestingly, parents or guardians committed an offence if they knowingly caused or permitted youth to be employed in contravention of the SSA. ${ }^{173}$

The MTA is silent as to the skills required to be a seafarer, whereas the SSA contained detailed provisions. It is obvious that, given the manual aspects of their role, seafarers need to be fit and able and it was an offence to ignore this requirement or to fraudulently obtain or use certification dictating that a seafarer was able-bodied. ${ }^{174}$ For example, a seafarer needed to serve as a trimmer for three months before progressing to a fireman or greaser. ${ }^{175}$ Cooks also had to have a certificate of competency and it was an offence if any person faked, forged or fraudulently altered this document. ${ }^{176}$ Regulations could dictate the issuing of medical fitness certificates and it was an offence to fail to comply. ${ }^{177}$

\section{b. Wages and compensation}

There are no provisions in the MTA relating to the payment of maritime wages. In the SSA, the obligation to pay seafarers lay with the master (and the owner) and not to do so was an offence. ${ }^{178}$ The master had to pay seafarers, even if they were left behind, ${ }^{179}$ within prescribed time limits and following legislative direction. Under the SSA there were also historical provisions relating to the master having to set up facilities for seafarers to receive remitted wages to a relative or a savings

\footnotetext{
172 Sections 49(12) and 182 of the SSA. There were strict requirements surrounding the apprentice indenture under the SSA (sections 29(6) and 30(3)). Apprentices were allowed and a master committed an offence if the apprentice was not 15 years old or of sufficient health and strength (section 29(6)). There is no comparable apprentice scheme in the MTA.

173 Section 49(12) of the SSA.

${ }^{174}$ Able-bodied was referred to as "A.B." in the SSA: See section.

175 Sections 53 and 54.

176 Section 136(7).

177 Section 140.

178 Section 89 of the SSA; section 113 of the Industrial Relations Act 1973; and section 145 of the Industrial Conciliation and Arbitration Act 1925.

${ }^{179}$ Sections 120(2) and 121(6) of the SSA.
} 
bank; ${ }^{180}$ setting out the time and mode of payment; ${ }^{181}$ and imprisonment for up to five years for every person who granted money orders for a fraudulent intent. ${ }^{182}$ It was previously illegal for any person to receive remuneration for providing employment to a seafarer. ${ }^{183}$

\section{c. Termination of employment}

The MTA does not provide any situations where employment will be terminated; the SSA did provide such situations. Seafarers' employment could be discharged only in accordance with the Act otherwise the master committed an offence. A discharge had to occur in front of a superintendent; ${ }^{184}$ a certificate of discharge was an entitlement; 185 and if discharge happened outside of NZ then there were specific mandatory rules to follow. ${ }^{186}$ The certificate of discharge was an important document for seafarers to have by right and this is highlighted by the penalties whereby a master found guilty of failing to provide a certificate would be liable to pay the effected seafarer the sum of one day's pay for every day that certification was withheld. ${ }^{187}$ Upon a change in master, the old master was under an obligation to hand over all the documentation in his custody relating to stability, the navigation of the ship, and relating to the crew..$^{188}$

Alongside the master's obligations in the SSA, were the obvious obligations on the seafarer themselves. These were reasonable but were not replicated in the MTA. Seafarers were criminalised if they made a false report; altered a certificate of discharge; assisted someone to commit fraud; or used an altered, false or forged certificate. ${ }^{189}$ If a seaman failed to make the voyage due to illness or accident,

\footnotetext{
180 Section 86(2).

${ }^{181}$ Section $87(3)$.

182 Section 87(3).

${ }^{183}$ Section 48.

${ }^{184}$ Section 57(2).

185 Section 58(6).

186 Sections 60(4) and 61(4).

187 Sections 58(7) and 61(5).

${ }^{188}$ Section 176(2).

189 Section 63.
} 
discharge was deemed ${ }^{190}$ and the master had the reasonable duty to advise the authorities and organise the attendance of a medical examination. ${ }^{191}$ The SSA also required seafarers to be paid their wages in the presence of the superintendent when discharged. ${ }^{192}$

\section{d. Employment and references}

The MTA contains an offence regarding the employment of seafarers in a narrow area: Every person is liable if they knowingly employ seafarers without appropriate maritime documentation. ${ }^{193}$ Presumably, the onus is on seafarers themselves to produce satisfactory documentation but the master must request it in order to satisfy his obligations. This was an offence against the master under the SSA. ${ }^{194}$ Seafarers were guilty of an offence if they made a false statement as to their last ship or their identity 195 and every person was liable for an offence if he offered himself, or knowingly offered a suspended person, for employment. 196 This would obviously cover seafarers. Likewise, a seaman had to produce his certificate of previous discharge before signing an agreement - if he failed to do so (or falsely declared) the existence of such certificate, he was liable upon summary conviction for up to three months imprisonment of a fine of $\$ 200 .{ }^{197}$

\section{e. Obligations on birth or death}

Once again, the MTA does not provide any obligations or offences on the birth or death of someone on-board a ship. In the SSA, the master had to record births and

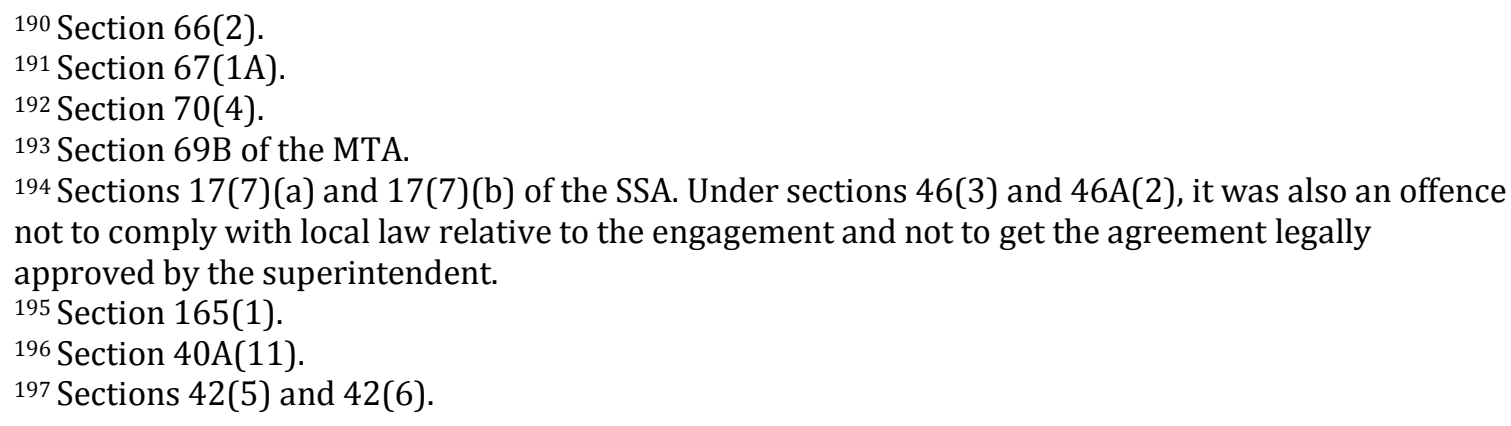


deaths on-board in his logbook and register the birth within 48 hours of arrival at a NZ or commonwealth port otherwise an offence was committed. ${ }^{198}$

The SSA also contained an offence relating to the failure abroad to comply with provisions of the Act as to the property of deceased seaman or seamen left behind. ${ }^{199}$ The penalty of this offence shows the severity of this action: a fine not exceeding three times the value of the property or, if value cannot be ascertained, up to $\$ 200.200$ As with other parts in the SSA, it was also an offence to forge or fraudulently alter any document to obtain such property, which was punishable by up to five years imprisonment. ${ }^{201}$ The master committed an offence if a body of a deceased seaman was not buried on shore "with all convenient dispatch". 202

\section{f. Discipline}

The MTA does not deal with crimes of discipline nor the failure to report for duty. ${ }^{203}$ This was a particular concern under the SSA: it was an offence to combine with other crew to disobey orders, neglect duties or impede the ship or its voyage ${ }^{204}$ and to not report for duties without reasonable cause. ${ }^{205}$ If a seafarer received an advance or money for expenses, and wilfully, or through misconduct, failed to join his ship then he was liable for a months' imprisonment as well as a fine. ${ }^{206}$ The master also had discretion to withhold non-reporting crew their discharge certification for up to a month meaning they could not be legally employed on another vessel. ${ }^{207}$ Similarly, the SSA also has detailed offences relating to enticing a

\footnotetext{
198 Section 506.

199 Section 104.

200 Section 104.

201 Section 115.

202 Section 186.

203 The Maritime Crimes Act 1999 does cover some discipline crimes as relating to terrorism. The SSA went further than criminalising terrorist acts.

204 Section 164 (d) of the SSA. The penalty under this offence range from up to one months' imprisonment, forfeiting wages of up to one months' pay, or a fine not exceeding $\$ 100$.

205 Sections 44(3) and 164(a). Seafarers forfeited two days' pay if they committed an offence by deserting or absented themselves without leave: Section 157(2).

206 Section 82.

207 Section 44(4). There were obligations on the master in this situation. If a seafarer failed to report before the ship set sail from NZ, the master may be required to lodge their wages and certificate of discharge with the superintendent as well as making a corresponding entry in the logbook (section 65(2)). If a seafarer was left behind, a certificate of a proper officer was required whether the cause
} 
seafarer to desert their ship or stowing away on a vessel (or helping someone else to stow away or desert). ${ }^{208}$ The SSA also outlined specific discipline requirements as it was an offence to disobey lawful instructions from a master; ${ }^{209}$ continually neglect duties; ${ }^{210}$ assault another seafarer (including the master); ${ }^{211}$ for a master to assault any seafarer; 212 wilfully damage or steal ship property, stores or cargo; ${ }^{213}$ or smuggle items. ${ }^{214}$

\section{g. Impairment of duties}

All seafarers, whether master or crew, have an obligation to not undertake their professional duties while intoxicated. It is an offence for any seafarer to perform, or attempt to perform, designated safety, security, or marine environmental duties on a ship while intoxicated. ${ }^{215}$ The levels of intoxication must not exceed a breath alcohol limit of $250 \mathrm{ml}$ per litre of breath or blood alcohol limit of $50 \mathrm{ml}$ per $100 \mathrm{ml}$ of blood. ${ }^{216}$ The penalties highlight the seriousness of this offence: penalties are imprisonment of up to 12 months or a fine not exceeding $\$ 10,000.217$ There are also related offences regarding refusal of testing by an enforcement officer (the police) with the same penalties. ${ }^{218}$ Seafarers can be arrested without warrant for suspicion of breaching these sections. ${ }^{219}$ The SSA did not state a particular level of intoxication as to create an offence, but if loss or

was unfitness, inability to continue to sea, desertion, disappearance, or any other reason (section 119(3)). The master was criminally liable for not providing this certification without cause. ${ }^{208}$ Section 173(1). Offences also applied to foreign ships per section 477. ${ }^{209}$ Sections 164(b) and 164(c). The penalties under these sections range from up to three months' imprisonment, a fine not exceed $\$ 40$, or forfeiting wages.

${ }^{210}$ Sections 164(b) and 164(c). The penalties under these sections range from up to three months' imprisonment, a fine not exceed $\$ 40$, or forfeiting wages.

${ }^{211}$ Section 164(e). The penalties for this offence is imprisonment for a term not exceeding six months or to a fine not exceeding $\$ 100$.

${ }^{212}$ Section 164(1A). The penalties for this offence is imprisonment for a term not exceeding six months or to a fine not exceeding $\$ 100$.

${ }^{213}$ Section 164(f). The penalties for this offence is imprisonment for a term not exceeding 12 months or forfeiting wages.

${ }^{214}$ Section $164(\mathrm{~g})$. The penalty for this offence is to pay the master or owner a sum equal to the loss or damage suffered.

215 Section 40 of the MTA.

${ }^{216}$ Sections 40, 40C(1) and40C(2).

217 Section 40.

${ }^{218}$ Sections 40D and 40E.

${ }^{219}$ Section 40F. 
damage to the ship or persons happened due to wilful breach or neglect of duty, or while in a state of intoxication, then the seafarer committed a criminal offence. ${ }^{220}$ These offences are comparable in practice.

These sections of the MTA were recently amended by the Maritime Transport Amendment Act 2013 to implement international standards to establish a globally applicable alcohol limit for merchant seafarers. ${ }^{221}$ The level of intoxication is the same for drivers of NZ roads after the 2014 amendments to the Land Transport Act 1998. Employers are able to impose a lower limit as the two Cook Strait ferry operators have reportedly done with a zero-alcohol limit. ${ }^{222}$ The first successful prosecution under these provisions occurred in March 2015 when Captain Kumar of the African Harrier (a 37,000 tonne fertilizer carrier ship) pleaded guilty in the Tauranga District when found with a breath alcohol limit of 1229 micrograms more than five times the intoxication limit. ${ }^{223} \mathrm{He}$ was fined $\$ 3,000.224$

This statutory level of intoxication reflects consensus of global best practice as applied to seafarers' on-board merchant seagoing ships. ${ }^{225}$ Interestingly, while international law in this area mentions both alcohol and drugs levels, it only imposes testing for alcohol. ${ }^{226}$ The amendments to the MTA follow this and only mandate testing for alcohol intoxication. Drug testing can be directed by owners of ships (as employers) for fitness for duty or general health and safety concerns. ${ }^{227}$ The practical effect of these amendments on seafarers is yet to be reported on.

\footnotetext{
220 Section 163 of the SSA.

221 Section 12 of the Maritime Transport Amendment Act 2013 which was previously the Marine Legislation Bill 2012; Maurice Williamson (11 September 2012) 683 NZPD 5080; and International Convention on Standards of Training, Certification and Watchkeeping for Seafarers 1367 UNTS 1362 (opened for signature 7 July 1978, entered into force 28 April 1984).

222 Phil Twyford (Labour) (11 September 2012) 683 NZPD 5080.

${ }^{223}$ Section 40B of the MTA; Maritime New Zealand "Maritime NZ welcomes sentencing of Master with excess breath alcohol" (23 March 2015) Maritime New Zealand <www.maritimenz.govt.nz>; and Sandra Conchie "Ship master five times over alcohol limit" (23 March 2015) New Zealand Herald <www.nzherald.co.nz>.

224 Maritime New Zealand, as above.

225 Ministry of Transport and Ministry for the Environment above n 116, at 69.

226 At 69-70. The Convention does not mandate random testing for either: at 70.

227 At 70.
} 


\section{Financial and regulatory responsibilities}

The maritime industry requires financial, investment and insurance input. The master or the owner will oversee most of these inputs under Part 24 of the MTA. However, there are a couple of incidents whereby seafarers individually could be held responsible for breaches. For example, there are comprehensive obligations relating to the payment of the oil pollution fund and levies. ${ }^{228}$ Levies must be paid to obtain a certificate of clearance. If this Part is not complied with, then every person commits a crime. ${ }^{229}$ The onus here really lies with the master or owner but the wording of the Act suggests that seafarers could also be prosecuted.

Insurance omissions have criminal liability in the MTA. It is an offence for the master to enter or leave NZ waters without a certificate of insurance and a bunker oil certificate of insurance (if required). ${ }^{230}$ Penalties for this nonexistence of insurance are the maximum penalties provided in the MTA (relating to the discharge of pollution): ${ }^{231}$ Imprisonment of up to two years or a fine not exceeding $\$ 200,000 .^{232}$ There are a few additional minor offences that the master would be liable for relating to carrying insurance or failing to produce the certificates upon request. ${ }^{233}$ There is a 'reasonable excuse' partial defence) which may protect the master against fake or fictitious policies that are unknown to the master. ${ }^{234}$

\section{E Administration of justice}

Offences relating to the administration of justice occur in all pieces of legislation involving authorities; the maritime industry is no exception. This area of criminalisation could apply in a number of diverse situations outside of the areas of risk previously discussed in this paper. The MTA contains numerous offences relating to the administration of justice such as obstruction or prevention of authorised personnel from performing duties. There is a catch-all offence whereby if

\footnotetext{
228 See Sections 333 and 337 of the MTA for example.

${ }^{229}$ Section 340(2). Levies are required under section 338.

230 Section $367(1)$.

231 See section 327.

232 Section $367(1)$.

233 Sections 367(2) and 367(3).

234 See section $367(1)$.
} 
the MTA says a record must be maintained, then every person commits an offence if they fail to do so. ${ }^{235}$ Unsurprisingly, these offences also existed in the SSA. The SSA outlined each obligation alongside the requirement to maintain or present documents if requested but in substance the obligations in the SSA and MTA are the same. ${ }^{236}$ There is no increased criminalisation here.

\section{a. Obstruction}

There is a wide obligation in the MTA whereby every person is guilty of an offence if they obstruct, impede, delay, hinder or deceive any person acting under the $\mathrm{MTA}^{237}$ or under previous legislation. ${ }^{238}$ It is a defence if evidence of authority is not produced. ${ }^{239}$ These MTA offences may be triggered if, for example, any person physically obstructs an enforcement officer (the police) from testing a seafarer for alcohol intoxication. There were comparable offences for wilful obstruction of surveyors and inspectors in the SSA that were applicable to every person, including all seafarers. ${ }^{240}$ If any person failed to comply with orders from appropriate authorities, or wilfully obstructed the authorities, the MPA created an offence punishable by a fine not exceeding $\$ 500,241$ or $\$ 10,000$ for each day of noncompliance if the Minister makes the orders which are disobeyed. ${ }^{242}$ The SSA also

\footnotetext{
235 Section 405.

236 Previous offences included: anyone failing to comply with a legal request to produce documentation (section 78(2) of the SSA); against a master for not maintaining an official logbook stating discharge of employment, provisions, illness, death, or wages of deceased seafarers (sections $177,178 \mathrm{~A}$ and 183 of the SSA); if the aforementioned logbook was not delivered by the master to the superintendent within 48 hours or within six months if the ship was being transferred (section $179(3)$ of the SSA); if the master did not deposit required documents within 48 hours of arriving at a foreign port (sections 180 and 189(4) of the SSA); against chief engineers who failed to maintain an engine room log (section 181(8) of the SSA); for anyone if a logbook entry was not made on every occasion involving the discharge of oil (section 11(1) of the MPA); or if any person made a fraudulently or misleading record in the logbook under the MPA (section 11(8) of the MPA). The preceding offences are now covered by the general provision of the MTA (section 405).

${ }^{237}$ Section $404(1)$ of the MTA.

${ }^{238}$ Section $15 \mathrm{H}(6)$ of the SSA.

${ }^{239}$ Section 404(4) of the MTA.

${ }^{240}$ See sections 15E(7)(a), 15E(7)(b), 15E(6) and 15G(6) of the SSA. The master, crew and passengers are expressly mentioned in section $15 \mathrm{E}(6)$ of the SSA.

${ }^{241}$ Section $17(8)$ of the MPA.

${ }^{242}$ Section 28.
} 
made it an offence if the master refused to let crew go ashore to complain about

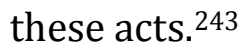

These provisions are reasonable and extend to all persons by virtue of general criminal law. Thus, it is rational that seafarers may face prosecution for these obstruction offences. In practice this charge has been discussed, not but used, against Greenpeace activists protesting Petrobras drilling off the East Coast of NZ,244 and hypothetically section 405 could have been applied to the Greenpeace activists who protested in the Artic at the Prirazlomnaya platform in Russia if the same facts occurred in NZ. 245

\section{b. False information}

In the MTA there is a catch-all offence relating to giving false, fraudulent or misleading information whereby every person in breach of this section faces up to 12 months imprisonment or a $\$ 10,000$ fine. ${ }^{246}$ The penalty identifies that this is a serious offence, but one which exists in all pieces of legislation where information is to be exchanged with officials. ${ }^{247}$ In the SSA, such provisions were generally stipulated per document rather than in a catch-all provision as in the MTA. Though, both legislative frameworks would operate the same in practice. ${ }^{248}$

It was also an offence against every person who certified, forged or tampered with evidence in proceedings ${ }^{249}$ and a crime for anyone who forged or misused documents generally. 250 There is a comparable offence in the MTA for every person

\footnotetext{
243 Section 151(3) of the SSA.

244 Aaron Gray-Block "Petrobras abandons plans for deep sea oil drilling in New Zealand" (4 December 2012) Greenpeace International <www.greenpeace.org>; and Bevan Marten "International recent developments: New Zealand” (2014) 38 Tulane Maritime Law Journal 623 at 633.

245 “Activists, actor Lucy Lawless arrested for Shell Arctic drillship occupation" (27 February 2012) Greenpeace International <www.greenpeace.org>.

246 Sections 406, and 407(3) of the MTA.

247 See section 342 of the Immigration Act 2009; section 231 of the Fisheries Act 1996; and sections 46B, 46C, 46D, 49, 52C, and 56 of the Civil Aviation Act 1990.

248 Such as section 63 of the SSA relating to a certificate of discharge.

249 Section 494.

250 Section 503.
} 
who communicates false information, knowing such information to be false, affecting the safety of a product, ship or facility. ${ }^{251}$

\section{What would happen in NZ?}

This paper will now discuss what would hypothetically happen under NZ law if the facts from four infamous international scenarios occurred in NZ. This analysis involves guesswork and such results may turn out different than mentioned below as a result of many factors, including political reaction and mitigations. It is evident from the discussion in Part IV that the SSA contained detailed offences compared to the generalist provisions in the MTA. This difference reveals itself in these cases as seafarers in Erika, Prestige, Nissos Amorgos and Tasman Spirit would likely be charged under the same MTA provisions. There is not the same range of penalties in $\mathrm{NZ}$ as available in some overseas jurisdictions and thus it is becomes evident that criminalisation in NZ would not occur to the same extent. Current penalties under NZ law are significantly more reasonable than in some other coastal states.

Also discussed hereunder is the Rena case; this case prompted a domestic discussion of criminalisation in the maritime industry. This case is important as an example of what happened in practice in this legal area and thus informs the hypothetical situations that follow.

\section{A Rena prosecution}

This criminalisation discussion was reflected in the NZ media in 2011 after the grounding of Rena; this provides the primary NZ case study involving criminal prosecutions relating to health and safety and pollution offences. The container ship Rena, built in 1990, was a Liberian-flagged, Greek-owned, container ship which was travelling in NZ waters after leaving Napier to Tauranga. ${ }^{252}$ In the early hours of 5

251 Section 67(1) the MTA.

252 Marten, above n 245, at 623; Transport Accident Investigation Commission Interim Report: Marine inquiry 11-204 Containership MV Rena grounding on Astrolabe Reef 5 October 2011 (2012) at iii; and Kerryn Webster and Felicity Monterio "Assessing the Impact of the Rena Disaster" Wilson Harle <http://www.wilsonharle.com/assessing-the-impact-of-the-rena-disaster>. 
October 2011, the Rena struck the Astrolabe Reef off the coast of Tauranga carrying approximately 1400 containers and an estimated 1700 tonnes of fuel. ${ }^{253}$

The Master of the Rena, Captain Balomaga, was charged under section 65(1) of the MTA for operating a vessel in a manner causing unnecessary danger or risk. ${ }^{254}$ The second officer in charge of navigation, Laonil Relon, faced almost identical charges. ${ }^{255}$ The two seafarers plead guilty to these charges on 29 February 2012 and were sentenced to seven months' imprisonment on 25 May 2012. ${ }^{256}$ This was the correct outcome as an "example of a justifiable exercise of criminal jurisdiction against seafarers" as their navigation was negligent and directly affected NZ's waters, environment and personal property. ${ }^{257}$ In this case, unlike some of the earlier cases examined in this paper, criminalisation was appropriate due to the gross negligence of those seafarers charged. ${ }^{258}$

This incident highlighted some failings of the current legislative regime, particularly in relation to insurance and the recovery of costs. It was the catalyst for the 2013 reform of the MTA: "The fact of the matter is that there was a disaster in [NZ] that has led to this greater impetus for these protocols to be enacted through legislation."259 For the purposes of this paper however the criminalisation of

\footnotetext{
${ }^{253}$ Marten, as above, at 624; Transport Accident Investigation Commission, as above, at 1; and Webster and Monterio, as above.

${ }^{254}$ Captain Balomaga was also charged under section 338(1)(b) of the RMA for discharging harmful substance into the water from a ship and under section 116 of the Crimes Act 1961 for wilfully attempting to pervert the course of justice by altering the ship's documents subsequent to the grounding. Detailed discussion on these charges are outside the scope of this paper.

255 Webster and Monterio, above n 253.

256 See Wolff J in Maritime New Zealand v Daina Shipping Company DC Tauranga CRI 2012-070-1872

26 October 2012; Marten, above n 245, at 623; Webster and Monterio, above n 253; and Alexis Lai "Captain pleads guilty over New Zealand cargo ship disaster" (6 March 2012) CNN <www.cnn.com>. 257 Bevan Marten "Submission on the Marine Legislation Bill” (8 October 2012) at [15]. 258 See Transport Accident Investigation Commission, above $\mathrm{n} 253$, at 1 . The owner of the Rena Daina Shipping Company, a Liberian shell company - was fined $\$ 300,000$ for breaching section 338(1)(b) of the RMA after a guilty plea. The charterer of the vessel, the Mediterranean Shipping Company, was not charged in relation to the grounding. These findings are outside the scoop of this paper. For further discussions see: Transport Accident Investigation Commission, above n 253, at 10; Maritime New Zealand v Daina Shipping Company (unreported) District Court, Tauranga, CRI 2012070-1872, 26 October 2012, Wolff J; Marten, above n 245, at 625; “Rena owners fined \$300,000" (26 October 2012) Bay of Plenty Times <www.nzherald.co.nz>; and Webster and Monterio, above n 253. 259 Jami-Lee Ross (National), (11 September 2012) 683 NZPD 5080.
} 
seafarers did not change under these reforms; such reforms were focused on shipowners and port operators' liability.

\section{B Future possibilities}

The biggest area of criminal responsibility in international maritime discourse is pollution. Criminal cases involving pollution and its after effects far outnumber any other examples. I thus examined four cases - the Erika, Prestige, Nissos Amorgos and Tasman Spirit - and applied their facts to hypothetical NZ situations. While these four cases contain vastly different fact scenarios and offenders received varying penalties in reality, in NZ the masters would likely be charged under the same MTA provisions and receive drastically lower punishments. Some seafarers were acquitted, however the risk of charges remain, and it is evident that the penalty they are risking under criminal law in NZ is lower than elsewhere (particularly in France).

It must also be remembered that general criminal law may also apply to the same acts undertaken by seafarers when undertaking their professional roles. For example, the Captains of both Sewol and Zim Mexico (as discussed in Part II) would likely face wrongful death (manslaughter) charges under the Crimes Act 1961 or for the discharge of harmful substances into the water from a ship under the RMA. ${ }^{260}$ This application of general criminal law is outside the scope of this paper though the regimes may overlap; I focus on current liability under the MTA.

\section{a. Negligent safety certification - Erika}

The Indian Master of Erika, Captain Mathur, was arrested in France when his ship caused oil pollution damage in December 1999 that was, at least partly, outside his knowledge. ${ }^{261}$ The Maltese-flagged Italian owned tanker, which was almost 25

${ }^{260}$ Alongside the MTA charges, Captain Balomaga of the Rena was convicted under this section 338(1)(b) of the RMA. He was also convicted under section 116 of the Crimes Act 1961 for wilfully attempting to pervert the course of justice by altering the ship's documents subsequent to the grounding.

${ }^{261}$ International Transport Workers' Federation, above n 1, at 30. The Captain and crew were later praised for managing to launch a lifeboat in tough weather: Permanent Commission of Enquiry into Accidents at Seas, above n 45, at 33. 
years old, broke in two after weathering storm damage, eventually sinking 60 miles off Penmarch Point in Brittany, France. It spilled an estimated 14,000 tonnes of oil into the ocean causing large-scale devastation to the water, to wildlife and to property. ${ }^{262}$ At the time of its sinking, the tanker was chartered by Total-Fina-Elf in good faith based on the safety certification issued by RINA (an Italian shipping classification society). ${ }^{263}$ The ship had current certification - meaning she was considered 'safe' - and she was travelling with the correct certifications required by law and industry.

Captain Karun was arrested and charged with causing pollution at sea and endangering the lives of others, despite having no responsibility for the certifications and the accumulation of rust and poor wear of Erika due to her age. 264 Captain Karun's "reputation and moral are in tatters" due to this imprisonment:265

...'What about the other players? For no fault of my own I am being put in prison! I am only operating the ship and I am the one who is jailed. I am not the one who owned the ship. What about the rest?'

He was eventually acquitted of all charges by the Paris Tribunal after eight years of legal proceedings. ${ }^{266}$ The resulting environmental mess from this ship became the catalyst for European reform and prompted EU legislative changes as discussed in Part II(B).

Given ships rely heavily on industry certification, and that the age of merchant ships is ever increasing due to the slowing of demand and international exports by water, it is not far-fetched that a similar disaster may happen in NZ

\footnotetext{
262 See Permanent Commission of Enquiry into Accidents at Seas, above n 45; Hare, above n 6, at 3; Oving, above n 6, at 6; and "The scandal of the Erika" (16 August 2000) BBC News

$<$ http://news.bbc.co.uk>.

263 Permanent Commission of Enquiry into Accidents at Seas, above $n$ 45, at [3]; Oving, above $n$ 6, at 6; and "The scandal of the Erika," as above.

264 "The scandal of the Erika," as above.

265 As above.

266 Oving, above n 6, at 6; and Vincent Foley and Christopher Nolan "In the Erika judgment Environmental liability and places of refuge: A sea change in civil and criminal responsibility that the maritime community must heed" (2008) 33 Tulane Maritime Law Journal 41 at 44.
} 
waters. $^{267}$ This case is analogous to Rena but with over eight times the fuel leakage. Captain Karun would be charged with the same offences under the MTA (operating a vessel in a manner causing unnecessary danger or risk) and would face 12 months imprisonment or a fine of up to $\$ 10,000$ for each day of delay. ${ }^{268}$ These MTA penalties are however greater than under previous NZ legislation. For example, discharge or escape of oil from any ship was an offence under the MPA and the master would be liable for clean-up costs and a $\$ 50,000$ fine. ${ }^{269}$ This area of increased criminality echoes the intellectual concerns surrounding pollution and the natural environment - importantly, there is now the option of imprisonment as punishment.

Captain Karun may have also faced prosecution under the MTA as he allegedly did not notify authorities of the inability to contain the spill in a timely manner and may not have followed all directions when this became an emergency. ${ }^{270}$ The first offence has a fine of up to $\$ 10,000$; the latter offence (section 253) has a penalty of up to two years imprisonment or a fine of up to $\$ 200,000$ and $\$ 10,000$ penalty.

If guilty, Captain Karun faced substantially less penalties for all these offences than he faced under EU law, however they are larger than in previous NZ legislation. ${ }^{271}$

\section{b. Poor state of repair-Prestige}

Two years after Erika sunk, in November 2002 there was a similar pollution incident in which an elderly Master weathered the blame even though he did everything in his power to mitigate the effects of the unfortunate situation. This ship was the Prestige. ${ }^{272}$ Captain Mangouras was held accountable when his ship sunk off

\footnotetext{
267 See Maritime Knowledge Centre "International Shipping Facts and Figures - Information Resources on Trade, Safety, Security, Environment" (6 March 2012) International Maritime Knowledge Centre <www.imo.org> at [3.2] and [3.8]; and "The scandal of the Erika," above n 263. 268 Section $65(1)$ of the MTA.

269 Sections 10(a) and 21(2) of the MPA.

270 Sections $19(4), 253(4)$ and 317 of the MTA.

271 See above $\mathrm{n} 25$.

272 International Transport Workers' Federation, above n 1, at 30.
} 
the coasts of Spain and Brittany, leaking an approximate 64,000 tonnes of oil into the sea, despite attempting to find refuge from Spain, France and Portugal in order to undertake salvage operations. ${ }^{273}$ This caused the largest environmental disaster in Spanish history. ${ }^{274}$

Captain Mangouras was arrested at 70 years of age in Spain and held for three months with bail set at a high $€ 3,000,000 .{ }^{275}$ He remained in a Spanish jail for 85 days before bail was posted and he remained under house arrest for a further two years. ${ }^{276}$ Criminal legal proceedings continued against the Master for eight years despite most industry persons and organisations believing that he not at fault.277 Finally, aged 78, he was acquitted of all charges regarding negligence and pollution, but was convicted of disobeying Spanish authorities during the crisis and sentenced to nine months imprisonment (with time already served). ${ }^{278}$ The Prestige's chief engineer and a senior Spanish official were also ultimately acquitted; the ship's Filipino second officer is reportedly still on the run from authorities. ${ }^{279}$ The Spanish criminal court determined that it was impossible to establish criminal responsibility against the acquitted individuals as the disaster was partly due to the 26-year old tanker's poor state of repair.280 "Judges said the leak was caused by deficient maintenance which the crew did not know about"281 and thus individual seafarers should not be held criminally accountable for.

As with Erika, this case draws parallels with Rena but with a massive 37x more fuel leakage than Rena. Although he might still be acquitted, Captain Mangouras would likely face charges against operating a vessel in a manner causing unnecessary danger or risk and would face 12 months imprisonment or a fine of up

\footnotetext{
273 At 30.

274 Nautilus International, above n 8, at 10.

275 Hare, above n 6, at 3; International Transport Workers' Federation, above n 1, at 30; and Oving, above $n 6$, at 7 .

276 Hare, above n 6, at 3; and Oving, above n 6, at 7.

277 Nautilus International, above n 8, at 10.

278 "Prestige oil tanker disaster crew acquitted in Spain," above, n 45.

279 "Prestige oil tanker disaster crew acquitted in Spain," above, n 45.

280 Elisabeth O’Leary "Spain Court Clears Captain, Merchant Navy in Prestige Oil Spill” (13 November 2013) Rigzone <http://www.rigzone.com>.

281 As above.
} 
to $\$ 10,000$ for each day of delay, which is in no way comparable to the heavy penalties he faced under Spanish law (up to US\$3,000,000 and four years imprisonment). ${ }^{282} \mathrm{He}$ would also be charged with a similar offence to that of which he was eventually convicted of: failing to follow lawful instructions by those in authority facing a fine of $\$ 10,000$ and $\$ 2,000$ per day of non-compliance ${ }^{283}$ together with not following all directions when this became an emergency situation. ${ }^{284}$

\section{c. Pilotage-Nissos Amorgos and Tasman Spirit}

Globally, seafarers have been held accountable in criminal law for incidents when they were not in control of their vessel. In February 1997, Nissos Amorgos struck the bottom of Venezuela's Maracaibo Channel while under pilot. ${ }^{285}$ There was a pattern of recent groundings in this Channel and Nissos Amorgos was one of three tankers to run aground in just a two-week period. ${ }^{286}$ This time however, an estimated 7,000 tonnes of oil escaped from the ship. ${ }^{287}$ After a series of appeals Captain Spyropoulos was eventually acquitted of any criminal offence; the pilot and port authorities were never charged.288 In their investigations, the Venezuelan authorities found that there were underwater bank collapses as well as submerged objects in the seabed. This was outside of the knowledge of the seafarers as well as the authorities. ${ }^{289}$ This outcome is likely to be the same in NZ. 290

A similar situation happened five years later. In July 2003 a Maltese tanker ran aground at the entrance to Karachi Port, Pakistan while under licenced pilot from the port authority. ${ }^{291}$ This time there were no changes in the underwater geography

\footnotetext{
282 Section 65(1) of the MTA; and Heinrich Albert Braun "Legal impacts on masters and crews in pollution cases - a country wise comparison" (Diploma of Shipping thesis, Department of Nautical Studies and International Economics Course, Hochschule Bremen, Germany, 2003) at 62.

283 Sections 242 and 244(3) of the MTA.

284 Section 19(4).

285 Oving, above n 6, at 5-6.

286 At 5-6.

287 At 5-6.

288 At 5-6; and "Intertanko welcomes release of Master of Nissos Amorgos by Venezuela" (1

September 2011) Intertanko <https://www.intertanko.com>.

289 Oving, above $\mathrm{n}$ 6, at 5-6.

290 The only current requirement is if a ship proceeds without a pilot and should have had one under the MTA. Section 265(3) of the SSA.

291 Hare, above n 6, at 7.
} 
contributing to the crash. Tasman Spirit proceeded to break in half and an estimated 12,000 tonnes of oil initially spilled into the Arabian Sea. Seven crew members were arrested - including the Master, chief engineer, third officer, second engineer and quartermaster - and held for nine months and later released reportedly without charge. ${ }^{292}$ While these seafarers would not face any piloting charges, they may face similar charges to those discussed above in relation to Prestige and Erika.

\section{What is the 'worst case scenario'?}

I hypothetically looked at a 'worst case scenario' in NZ. An uninsured ship operating outside its prescribed limits runs aground, discharges oil and the intoxicated master makes the decision to store hazardous waste on the seabed before proceeding to a nearby port. The Captain would likely face the same MTA charges as Rena - operating a vessel in a manner causing unnecessary danger or risk - and would face 12 months imprisonment ${ }^{293}$ and $\$ 10,000$ and/or an additional 12 months imprisonment for operating a ship outside its limits. ${ }^{294} \mathrm{He}$ would also be liable for the two largest penalties under the MTA as the ship did not have the required insurance ${ }^{295}$ and for discharging harmful substances into the sea or seabed. ${ }^{296}$ Both of these offences have penalties of up to two years or a fine up to $\$ 200,000$. The Master will also be liable for storing waste on the seabed (for a fine of up to $\$ 200,000 ; \$ 10,000$ for each day of continuing offence; and costs associated with putting the act right), ${ }^{297}$ as well as an additional 12 months imprisonment or a fine not exceeding $\$ 10,000$ for being intoxicated while in charge of the vessel.298 There may be other minor offences that also attach to these facts, and mitigation actions may be apparent, however the point to note is that these offences against the Master equate up to seven years in prison and/or a fine of $\$ 620,000$ in this 'worst

\footnotetext{
292 As above 7; and "Pakistan tackles huge oil spill" (15 August 2003) BBC <http://news.bbc.co.uk>.

293 Section 65(1) of the MTA.

294 Section 67B(1)(b).

295 Sections 263(5) and 266.

296 Section 237.

297 Masters are also liable for three times the value of any commercial gain. Sections 263(5) and 266.

298 Sections 40, 40C(1) and40C(2).
} 
case scenario. ${ }^{299}$ These penalties are minimal compared to other jurisdictions, such as various EU states where the majority of fines range from $€ 150,000$ to $€ 1,500,000$ and imprisonment of up to five years. ${ }^{300}$ In France, high penalties of €15 million and 10 years' imprisonment attach intentional pollution acts alone. ${ }^{301}$ These facts illustrate that the penalties that attach to maritime criminal acts in NZ are comparably low in the international discussion.

\section{Conclusions}

I conclude that over the past fifty years, there has only been a minimal increase in the criminalisation of seafarers in NZ. Increased criminalisation has happened particularly in the area of pollution, including the handling dangerous or hazardous cargo. For example, there were no offences dealing specially with hazardous waste in previous NZ legislation; such situations would have fallen under all-purpose health and safety requirements of the SSA regarding dangerous goods or unseaworthiness. The increase in criminalisation in this area in NZ is reasonable having regard to the positions of responsibility and outcomes of wrongdoings.

This increase in pollution criminalisation is a product of the evolving nature of the maritime industry and education lessons from past disasters such as Erika and Prestige. The one recent case in NZ of holding seafarers criminal accountable in this area - Rena - shows that those in charge were held accountable, particularly the master: "The master is an easy target in shipping cases because he or she is physically present, in a position of responsibility, and subject to the local jurisdiction."302 This follows international trends due to learning from environmental disasters and is consistent with the master being held to a higher standard of care because they have more responsibility on-board. This high profile

299 This assumes that criminal penalties may attach cumulatively but I recognise in practice that this is highly unlikely to happen.

${ }^{300}$ Huybrechts above n 25, at 220; and Mitroussi, above n 1, at 1047. Some states go further than this EU standard.

${ }^{301}$ North P\&I, above n 25, at 5.

302 Marten, above n 258, at [16]. 
criminal case of Rena showed a correct attitude to those in charge who neglected their duties and caused significant damage.

Prosecutions are heavily reliant on the factual situations and very few have been subject to NZ court scrutiny so it is difficult to determine the scope of criminalisation in practice outside the Rena incident. I thus applied the facts of four infamous cases to hypothetical situations in NZ in light of Rena, and I found that all Captains may have faces charges under the same MTA provision as faced in Rena: operating a vessel in a manner causing unnecessary danger or risk (section 65(1)). The facts of each of the cases - Erika, Prestige, Nissos Amorgos and Tasman Spirit vary and thus it is difficult to predict what penalties would be imposed. In any event, the penalty under this provision, being 12 months imprisonment or a fine of up to $\$ 10,000$ for each day of delay, is significantly less than those in other jurisdictions: a global study indicated that average fines in EU states were approximately $£ 580,000$ for illegal discharges. ${ }^{303}$ The extreme example is France which affected the Captain of Erika, where fines range from $€ 800,000$ for lower-end pollution caused by negligence to $€ 15$ million and 10 years' imprisonment for intention pollution. ${ }^{304}$ The Captains may also face up to two years in prison and a fine of up to $\$ 200,000$ under NZ law if they do not follow directions from authorities, including MNZ, in an emergency, ${ }^{305}$ though this is reliant on the facts. Of course, the penalties may change having regard to the facts and mitigating situations.

More generally, I found that under NZ law, seafarers are not usually held criminally accountable for actions under maritime criminal law unless the act or omission is done intentionally. The burden of the vast majority of offences lies with the master in both the previous and current legislative frameworks, as they are the individuals with the obligation and the responsibility to influence situations. The master is the person in charge of a vessel and must follow the duties outlined in section 19 of the MTA. Thus the master is held to a higher standard as a person in

\footnotetext{
303 International Maritime Organization "Analysis and evaluation of deficiency reports and mandatory reports under MARPOL for 2011" in Giovannini, above n 20, at 47.

304 North P\&I, above n 25, at 5.

305 Section 19(4) of the MTA.
} 
responsibility and is expressly named in various offences contained the MTA. There is a much larger position of responsibility on the master with the outcome of criminal sanctions than those of a general seafarer.

This paper thus concludes that despite the industry claiming that there is a worrying trend towards criminalisation internationally, this is not a reality in NZ. Nothing in legislation or in practice has been uncovered to suggest that that vast or unreasonable criminalisation happens to seafarers. Masters are held to a greater standard due to their position of power in the shipping supply chain, as evidenced in Rena. The main area of increasing criminalisation against seafarers is in relation to pollution crime, including handling dangerous or hazardous cargo. The areas of increased criminalisation identified in Part IV of this paper reflect the global experience after environmental disasters, as well as NZ's obligations under international agreements, global advances and human rights and/or employment trends. There are no current offence provisions that are unreasonable and the development between the SSA and the MTA is reasonable. The idea that seafarers are disproportionality blamed in the criminal system for incidents seems to be a political argument in NZ rather than evidenced in the legislation and case law. I therefore conclude that the criminalisation of seafarers under the current NZ legislative framework is reasonable and there is no case law suggesting that this changes in practice. 


\section{BIBLIOGRAPHY}

\section{Primary sources}

\section{Legislation - New Zealand}

Civil Aviation Act 1990

Crimes Act 1961

Exclusive Economic Zone and Continental Shelf (Environmental Effects) Act 2012

Fisheries Act 1996

Health Act 1956

Health and Safety in Employment Amendment Act 2002

Immigration Act 2009

Industrial Conciliation and Arbitration Act 1925

Industrial Relations Act 1973

Land Transport Act 1998

Local Government Act 2002

Marine and Coastal Area (Takutai Moana) Act 2011

Marine Insurance Act 1908

Marine Legislation Bill 2012

Marine Pollution Act 1974

Maritime Crimes Act 1999

Maritime Security Act 2004

Maritime Transport Act 1994

Maritime Transport Amendment Act 2013

Misuse of Drugs Act 1975

Resource Management Act 1991 
Shipping and Seamen Act 1952

\section{Legislation - International}

Convention for the Suppression of Unlawful Acts Against the Safety of Maritime Navigation 1678 UNTS 1 (opened for signature 10 March 1988, entered into force 1 March 1992).

Council Framework Decision 2005/667/JHA [2005] OJ L 255/164.

Directive 2005/35 [2005] OJ L 255.

International Convention for the Safety of Life at Sea 1184 UNTS 1185 (opened for signature 1 November 1974, entered into force 25 May 1980).

International Convention of Pollution from Ships 1340 UNTS 1341 (opened for signature 17 February 1978, entered into force 2 October 1983).

International Convention on Standards of Training, Certification and Watchkeeping for Seafarers 1367 UNTS 1362 (opened for signature 7 July 1978, entered into force 28 April 1984).

Maritime Labour Convention 2006 International Labour Office (opened for signature 23 February 2006, entered into force 20 August 2013).

Protocol Relating to Intervention on the High Seas in Cases of Pollution by Substances other than Oil 1313 as modified by the Protocol of 1978 UNTS 1 (entered into force 30 March 1983).

Protocol to the Convention of 10 March 1988 for the Suppression of Unlawful Acts Against the Safety of Fixed Platforms Located on the Continental Shelf 1678 UNTS 1 (opened for signature 10 March 1988, entered into force 1 March 1992).

United Nations Convention on the Law of the Sea 1833 UNTS 3 copened for signature 10 December 1982, entered into force 16 November 1994).

\section{Cases - New Zealand}

New Zealand Police v Teddy [2013] NZHC 432. 
Maritime New Zealand v Daina Shipping Company DC Tauranga CRI 2012-070-1872 26 October 2012.

Maritime New Zealand v Page [2013] DCR 102.

Sellers v Maritime Safety (5 November 1998) CA104/98.

Parliamentary debates (HANSARD) - New Zealand

(24 September 2014) 693 NZPD 13614.

(12 June 2014) 5489 Questions for written answer.

(15 October 2013) 694 NZPD 13825.

(20 March 2013) 688 NZPD 8744.

(20 March 2013) 688 NZPD 8753.

(11 September 2012) 683 NZPD 5080.

(28 August 2012) 683 NZPD 4779.

(8 February 2012) 677 NZPD 168.

(7 February 2012) 677 NZPD 82.

(12 April 2011) 671 NZPD 17878.

(12 April 2011) 671 NZPD 18013.

(12 April 2011) 671 NZPD 18188.

(9 November 2004) 621 NZPD 16731.

(12 August 2004) 619 NZPD 14895.

(25 June 2003) 609 NZPD 6585.

$\underline{\text { Secondary sources }}$

\section{Books}

Yvonne Baatz (ed.) Maritime Law (3rd ed, Routledge, New York, 2014). 
Simon Baudghen Shipping Law (5 ${ }^{\text {th }}$ ed, Routledge, Oxon, United Kingdom, 2012).

David Caron and Harry Scheiber (eds.) The Oceans in the Nuclear Age: Legacies and Risks (Martinus Nijhoff Publishers, The Netherlands, 2010).

Malcolm Clarke (ed.) Maritime Law Evolving: Thirty Years at Southhampton (Hart Publishing Ltd, United Kingdom, 2013).

Jack Harris (ed) Maritime Law: Issues, Challenges and Implications (Nova Science Publishers, Inc., New York, 2011).

Jennifer Lavelle (ed) The Maritime Labour Convention 2006 (Informa Law from Routledge, Oxton, United Kingdom, 2014).

Norman Martinez Gutierrez (ed) Serving the Rule of International Maritime Law: Essays in Honour of Professor David Joseph Attard (Routledge, Oxton, United Kingdom, 2010).

Michael Faure, Han Lixin and Shan Hongjun (eds) Maritime Pollution Liability and Policy: China, Europe and the US (Kluwer Law International, The Netherlands 2010).

Alla Pozdnakova Criminal Jurisdiction over Perpetrators of Ship-Source Pollution (Martinus Nijhoff Publishers, The Netherlands, 2012).

\section{Journal articles and dissertations}

Olagunju Anthony "Criminalization of Seafarers for Accidental Discharge of Oil: Is there justification in international law for criminal sanction for negligent or accidental pollution of the sea?" (2006) 37 Journal of Maritime Law and Commerce 219.

Heinrich Albert Braun "Legal impacts on masters and crews in pollution cases - a country wise comparison" (Diploma of Shipping thesis, Department of Nautical Studies and International Economics Course, Hochschule Bremen, Germany, 2003).

Tom Broadmore "Ethics in Maritime law - New Zealand" (2014) 28 Australian and New Zealand Maritime Law Journal 58. Maria Rowena Buena-Hubilla "An Analytical 
Review of the Treatment of Seafarers under the Current Milieu of the International Law Relating to Maritime Labour and Human Rights." (Master of Science dissertation, World Maritime University, Malmo, Sweden, 2009).

Maria Rowena Buena-Hubilla "An Analytical Review of the Treatment of Seafarers under the Current Milieu of the International Law Relating to Maritime Labour and Human Rights." (Master of Science dissertation, World Maritime University, Malmo, Sweden, 2009).

Simon Daniels “The Criminalisation of the Ship's Master. A new approach for the new Millennium" (PhD thesis, Southampton Solent University, 2012).

Vincent Foley and Christopher Nolan "In the Erika judgment - Environmental liability and places of refuge: A sea change in civil and criminal responsibility that the maritime community must heed" (2008) 33 Tulane Maritime Law Journal 41.

Alexandros Goulielmos, Agisilaos Anastasakos, and Androniki Gatzoli "The Effect of Maritime Security Regime (ISPS Code) on World Supply of Seafarers" (2014) 64 SPOUDAI Journal of Economics and Business 63.

Chaynee Hodgetts "Hit and Miss: An Elementary Analysis of Domestic Criminal Statutes and Involuntary Manslaughter in Fatal Maritime Collisions and Near Miss Incidents" (2014) 78 Journal of Criminal Law 27.

Robert Iversen “The Mental Health of Seafarers” (2012) 63 International Maritime Health 78.

Michael Ekow Manuel "Potential sociological impacts of unfair treatment of seafarers" (2011) 38 Maritime Policy and Management 39.

Bevan Marten “International recent developments: New Zealand” (2014) 38 Tulane Maritime Law Journal 623.

Kyriaki Mitroussi "Employment of seafarers in the EU context: Challenges and opportunities" (2008) 32 Marine Policy 1043.

Ove Oving "Criminalisation of the ship's master and his crew" (2012) Kalmar Maritime Academy, Linnaeus University. 


\section{Parliamentary and government materials}

Ministry of Transport and Ministry for the Environment Marine Legislation Bill 2012: Report of the Ministry of Transport and the Ministry for the Environment (2012).

Marine Legislation Bill 2013 (select committee report) 58-2.

Maritime Transport Bill 1993 (select committee report) I.13A.

Parliamentary Commissioner for the Environment The Control of Marine Oil Pollution in New Zealand - A review of the system (Executive Summary) (1991).

\section{Reports}

European Commission Report from the Commission to the European Parliament and the Council: Report on liability and compensation for financial damages sustained by places of refuge when accommodating a ship in need of assistance (2012).

Transport Accident Investigation Commission Interim Report: Marine inquiry 11-204 Containership MV Rena grounding on Astrolabe Reef 5 October 2011 (2012).

\section{Internet Resources}

"Activists, actor Lucy Lawless arrested for Shell Arctic drillship occupation" (27 February 2012) Greenpeace International <www.greenpeace.org>.

Neil Beadle "The Rena's Cautionary Tale: Limitation of Liability in Marine Claims in New Zealand" (28 June 2013) DLA Phillips Fox <http://www.dlapf.com/rena\%E2\%80\%99s-cautionary-tale-limitation-liabilitymarine-claims-new-zealand\#.VJ8t2f_doA>.

Stephen Cahoon and Hilary Haugstetter "Shipping, Shortages and Generation Y" (2008) University of Tasmania <http://www.healert.org/filemanager/root/site_assets/standalone_article_pdfs_0605/he00760.pdfs. 
John Cartner "Seafarer Criminalisation - Poisoned well is a poor fate for anyone" (29 September 2010) <http://safewaters.wordpress.com/2010/09/29/seafarercriminalisation-poisoned-well-is-a-poor-fate-for-anyone/>.

John Cartner "Seafarer Criminalisation Rears Its Ugly Head" (20 October 2011) The Seafarer Times, Maritime News for Filipino Seafarers <https://seafarertimes.com>.

Michael Chalos and Eugene O'Connor "The ZIM Mexico III incident and the trial of Captain Schroeder - The complete saga" (1 August 2007) Grad News $<$ http://www.gard.no>.

"Criminalisation of seafarers? Sinking of the Queen of the North" (16 March 2011) Vancouver Lawyers <http://bht.com/>.

Sandra Conchie "Ship master five times over alcohol limit" (23 March 2015) New Zealand Herald <www.nzherald.co.nz>.

Adam Corbett "Union highlights police raids on seafarers' PCs" (10 September 2009) Tradewindsnews.com <http://www.tradewindsnews.com/".

Elisabeth Fontugne "Dismantling the Exxon Valdez: How Misunderstanding One Maritime Accident Led to the Criminalization of an Entire Profession" (28 April 2013) Stetson University <http://papers.ssrn.com/sol3/papers.cfm?abstract_id=2323263>.

Aaron Gray-Block "Petrobras abandons plans for deep sea oil drilling in New Zealand" (4 December 2012) Greenpeace International <www.greenpeace.org>.

"Intertanko welcomes release of Master of Nissos Amorgos by Venezuela" (1 September 2011) Intertanko <https://www.intertanko.com>.

Alexis Lai "Captain pleads guilty over New Zealand cargo ship disaster" (6 March 2012) CNN <www.cnn.com>.

"Lack of Due Process Breeds Fear of Criminalisation Among Seafarers" (25 April 2013) Seafarers' Rights International <http://worldmaritimenews.com/>. 
Maritime Knowledge Centre "International Shipping Facts and Figures - Information Resources on Trade, Safety, Security, Environment" (6 March 2012) International Maritime Knowledge Centre <www.imo.org>.

Maritime New Zealand "Fit and proper person check" <www.maritimenz.govt.nz>. Maritime New Zealand "Maritime NZ welcomes sentencing of Master with excess breath alcohol" (23 March 2015) Maritime New Zealand $<$ www.maritimenz.govt.nz>.

Maritime Union of New Zealand "Seafarers sound the alarm in world's ports" (30 September 2004) Scoop News <http://www.scoop.co.nz/>.

Nautilus International "Criminalisation of seafarers" <http://content.yudu.com/Library/A1vef6/Criminalisationofsea/resources/index.h tm?referrerUrl=http\%3A\%2F\%2Ffree.yudu.com\%2Fitem\%2Fdetails\%2F466362\% 2FCriminalisation-of-seafarers\%3Frefid\%3D44870>.

North P\&I "France hits polluters hard" (April 2009) Signals Newsletter $<$ www.nepia.com> at 5.

Elisabeth O'Leary Spain Court Clears Captain, Merchant Navy in Prestige Oil Spill" (13 November 2013) Rigzone <http://www.rigzone.com>.

"The scandal of the Erika" (16 August 2000) BBC News <http://news.bbc.co.uk>. “Pakistan tackles huge oil spill" (15 August 2003) BBC <http://news.bbc.co.uk>. Permanent Commission of Enquiry into Accidents at Sea "Report of the enquiry into the sinking of Erika off the coasts of Brittany on 12 December 1999" Permanent Commission of enquiry into accidents at sea <http://www.beamerfrance.org/BanqueDocument/pdf_87.pdf>.

"Prestige oil tanker disaster crew acquitted in Spain" (13 November 2013) BBC $<$ http://www.bbc.co.uk>.

“Rena owners fined \$300,000" (26 October 2012) Bay of Plenty Times $<$ www.nzherald.co.nz>. 
Joe Brady Stamford "Stalemate in 'Celine' saga" (18 August 2005) TradeWinds $<$ http://www.tradewindsnews.com>.

Lulu Trask "Criminalisation of crew remains a problem" (2 July 2013) The Crew Report <http://www.thecrewreport.com>.

Giles Tremlett "Cruel sea" (17 February 2004) The Guardian $<$ http://www.theguardian.com>.

Kerryn Webster and Felicity Monterio "Assessing the Impact of the Rena Disaster" Wilson Harle <http://www.wilsonharle.com/assessing-the-impact-of-the-renadisaster>.

\section{Other Resources}

Australian Maritime Digest "Call to Protect Seafarers from Criminal Action” (1 March 2008).

Australian Maritime Digest "Criminalisation and Piracy 'Damaging Seafarer Recruitment"' (1 April 2010).

Australian Maritime Digest "Criminalisation of Pollution Incidents Detrimental for Shipping" (1 March 2005).

Australian Maritime Digest "Criminalisation Threatens Future of World Shipping says IMO Chief" (1 July 2005).

John Cartner "Seafarer Criminalisation Rears Its Ugly Head" (19 October 2011) Lloyd's List 6.

Gary Dixon "Top union slams severity of Sewol crew sentences" (14 November 2014) Lloyd's List Australia 7.

Barnaby Eales “Getting away with murder?” (18 November 2014) Fairplay at 16.

Nicola Giovannini and others "Addressing Environmental Crimes and Marine Pollution in the EU" (2013) Droit au Droit, Brussels. 
John Hare "Criminalisation and Fair Treatment of Seafarers - Punishable Miscreants or Political Pawns?" (September 2011) The Nautical Institute Command Seminar, Cape Town.

International Transport Workers' Federation "What does the shipping crisis mean for seafarers?" (2009) Seafarers' Bulletin 23/2009.

International Transport Workers' Federation "Out of sight, out of mind: Seafarers, Fishers and Human Rights" June 2006.

John Ireland "Submission to the Transport and Industrial Relations Select Committee on the Marine Legislation Bill Section 67A Overloading Offence" (10 October 2012).

Sarah Kirby "The Criminalization of Seafarers Involved in Marine Pollution Incidents" (Company of Master Mariners of Canada International Conference 'Shipping and Environmental Issues in 2001 What more can be done?', Halifax, Nova Scotia, 7 June 2011).

Maritime Knowledge Centre "Information Resources on Fair Treatment of Seafarers: Abandonment, Personal Injury to or Death of Seafarers; Criminalisation of Seafarers in the event of Maritime Accidents Including Pollution Incidents and Shore Leave for Seafarers" (28 May 2013) International Maritime Organization.

Michael Lund "Speech for International Seminar of Russian Register of Shipping 2223 October 2008 Quality Shipping: XXI Century Standard. Seafaring Careers: Raising the Profile" (20 October 2008).

Maritime New Zealand "Building a sustainable organisation: Value for money review at Maritime New Zealand" (8 December 2010).

Bevan Marten "Submission on the Marine Legislation Bill" (8 October 2012).

Efthimios Mitropoulos, Secretary-General of the International Maritime Organization (presented by Rosalie Blakin) "Criminalisation of Masters and Seafarers Conference" (Criminalisation of Masters and Seafarers Conference, London, 17 February 2005). 
Ann Moore "Crime on the high seas" (18 November 2014) Fairplay at 18.

Olivia Murray "Criminalisation of Seafarers - Recent Developments: Presentation to the international Working Group on the Fair Treatment of Seafarers" INCE and Co.

New Zealand Shipping Federation "Submission on the Marine Legislation Bill" (12 October 2012).

David Osler "Sewol jail terms too harsh, say seafarer organisations" (20 November 2014) Lloyd's List Australia 9.

Faz Peermohamed and Olivia Murray "Criminalisation of Seafarers" (2012) The Swedish Club Triton 1-2012.

Sanford Limited "Health and Safety Reform Bill Sanford Limited Submission" (7 May 2014).

Seafarers International Research Centre "Seafarers International Research Centre Symposium Proceedings" (2011) Cardiff University. 